UNIVERSITEIT VAN PRETORIA

UNIVERSITY OF PRETORIA

Denkieiers

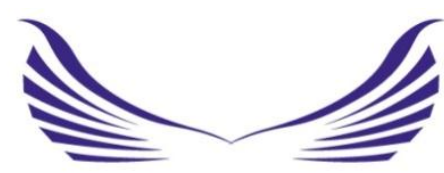

GORDON INSTITUTE

OF BUSINESS SCIENCE

University of Pretoria

\title{
Exchange rate policy and export performance in efficiency-driven economies
}

Nicola Kim Rowbotham

10648102

A research project submitted to the Gordon Institute of Business Science, University of Pretoria, in partial fulfilment of the requirements for the degree of Master of Business Administration.

9 November 2011

\section{Cell: 0716008894}

Tel: (011) 2824685

Email: nicola.rowbotham@rmb.co.za

(C) University of Pretoria 


\section{Abstract}

Increased globalisation of trade has led a growing number of firms to search beyond their traditional domestic markets. As a result, export-led growth has gained focus, particularly amongst industrialising nations, or so-called efficiencydriven economies, in search of economic growth. Policy prescriptions have generally proposed a weakening of the exchange rate as a means to stimulate exports; whilst an exchange rate appreciation would be detrimental to exports and encourage imports. Past research on this topic has been mixed.

This research examines the impact of exchange rate on export performance in a sample of nine efficiency-driven economies for the period from 1990 to 2009. These economies, with floating exchange rate arrangements, include Brazil, the Dominican Republic, Malaysia, Mauritius, Mexico, Peru, South Africa, Thailand and Turkey. Panel data models using a fixed-effects method have been applied in this research. The research finds that a weakening of the exchange rate does not necessarily improve export performance. To the contrary, export growth is associated with a stronger, relative exchange rate. The lag effect of exchange rate movement on export performance is slightly more pronounced, but remains statistically insignificant.

\section{Keywords}

Exchange rate, export performance, efficiency-driven economy 


\section{Declaration}

I declare that this research project is my own work. It is submitted in partial fulfilment of the requirements for the degree of Master of Business Administration at the Gordon Institute of Business Science, University of Pretoria. It has not been submitted before for any degree or examination in any other University. I further declare that I have obtained the necessary authorisation and consent to carry out this research.

Nicola Kim Rowbotham

9 November 2011 


\section{Acknowledgements}

The completion of this research report would not have been possible without the continued and valued support and assistance of a number of people.

To Professor Adrian Saville, my research supervisor, thank you for your guidance, encouragement and support.

To Hennie Gerber, your assistance from a statistical perspective was invaluable.

Most especially to my friends and family, thank you for all your support, understanding and constant encouragement. I could not have done this without you. 


\section{Table of Contents}

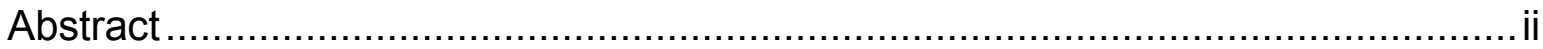

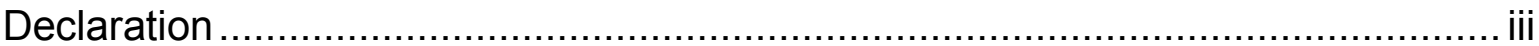

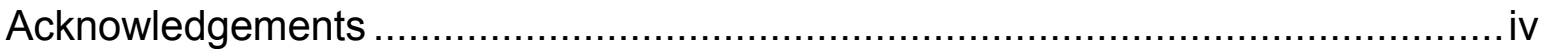

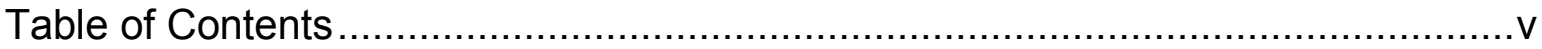

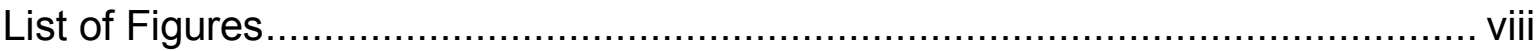

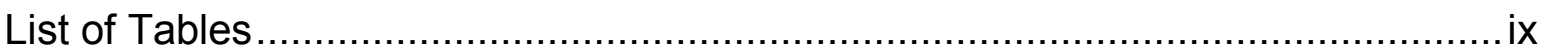

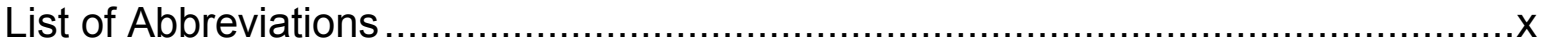

1. Introduction to the Research Problem ............................................... 1

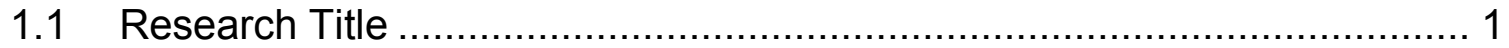

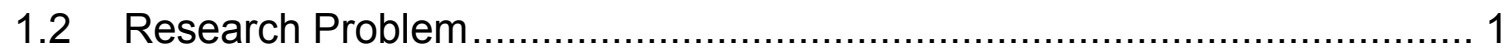

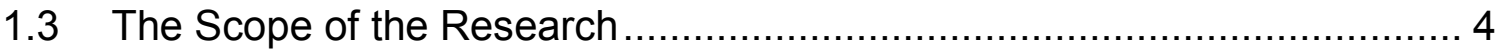

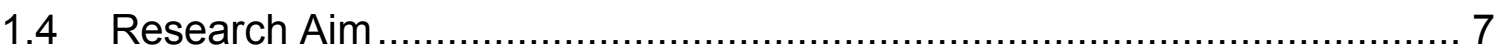

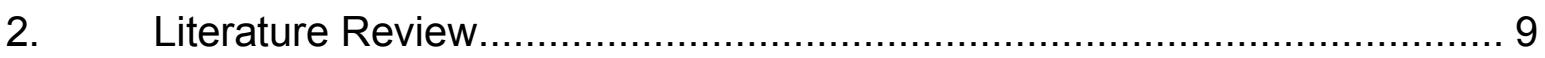

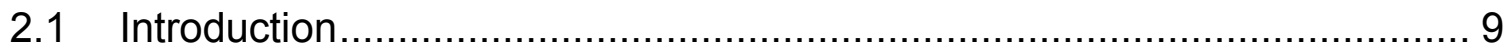

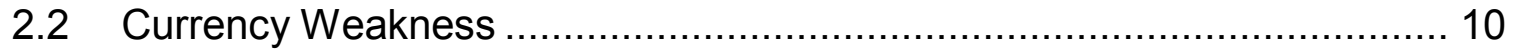

2.2.1 Nominal and Real Exchange Rates .......................................... 10

2.2.2 Exchange Rate Arrangements .............................................. 11

2.2.3 Devaluation versus Depreciation ............................................... 13

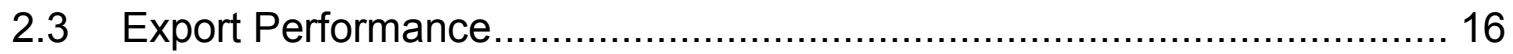

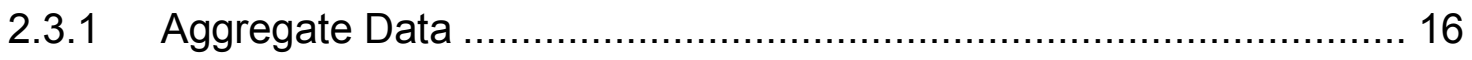

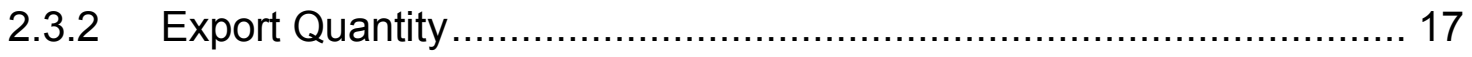

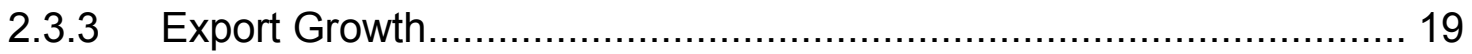

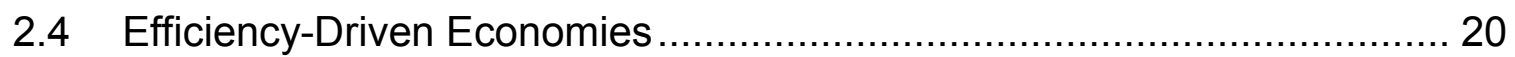


2.4.1 Developing Economies.

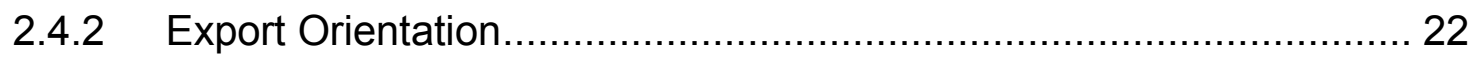

2.5 Currency Weakness and Export Performance .................................... 23

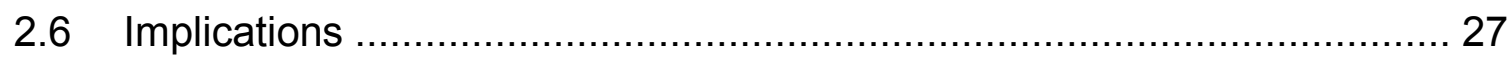

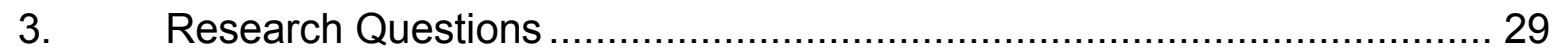

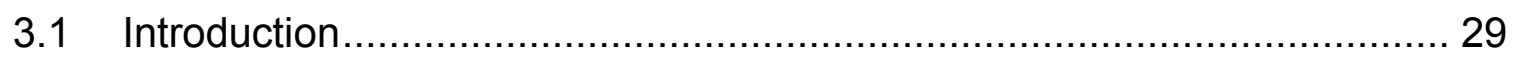

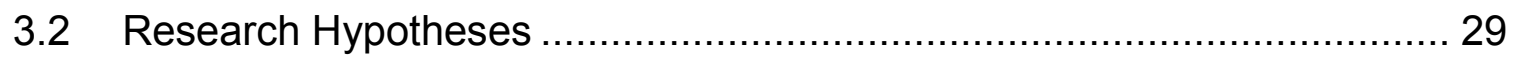

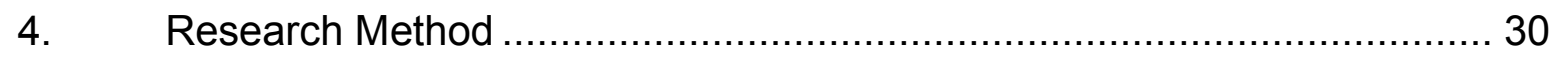

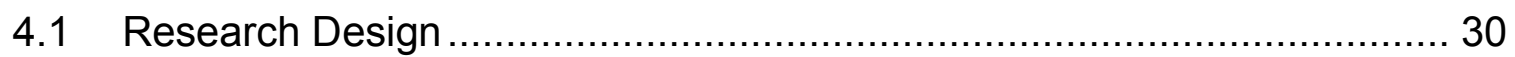

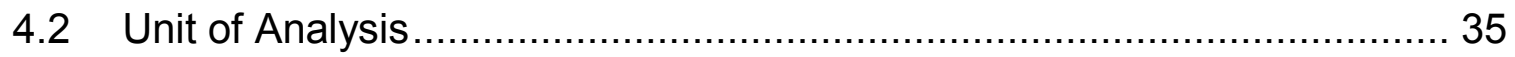

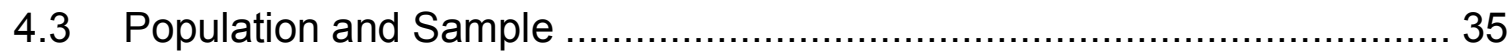

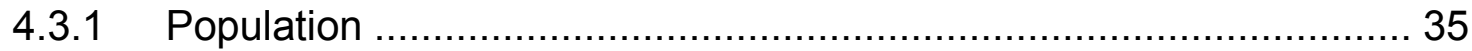

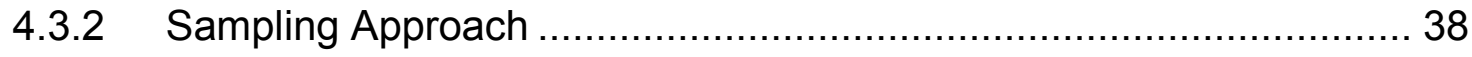

4.4 Data Collection and Analysis ........................................................ 42

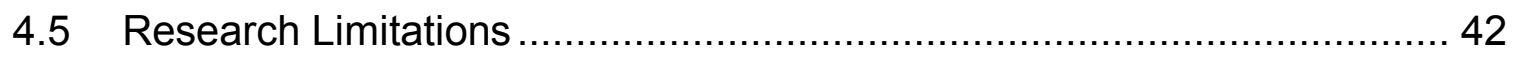

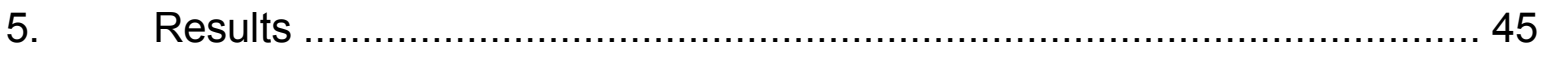

5.1 Sample Data and Descriptive Statistics ............................................. 45

5.2 Hypothesis One: Export Growth is Improved by Currency Depreciation in Efficiency-Driven Economies ........................................................... 52

5.3 Hypothesis Two: Improvements in Export Growth Lag Currency Depreciation in Efficiency-Driven Economies ........................................ 62

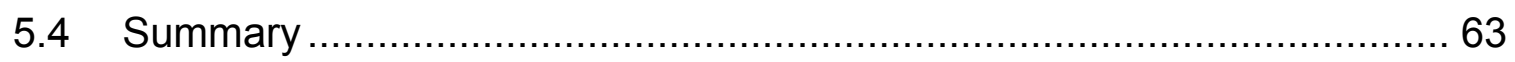

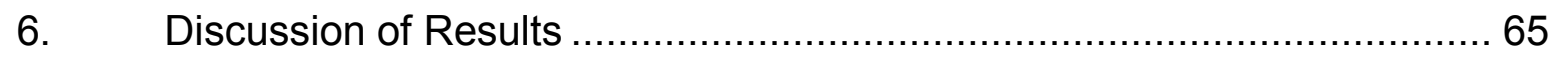

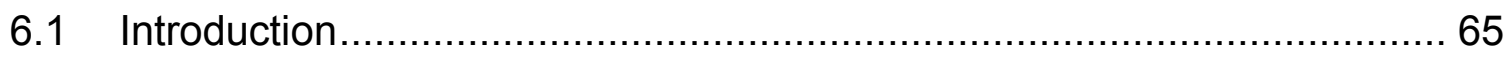

6.2 Hypothesis One: Export Growth is Improved by Currency Depreciation in

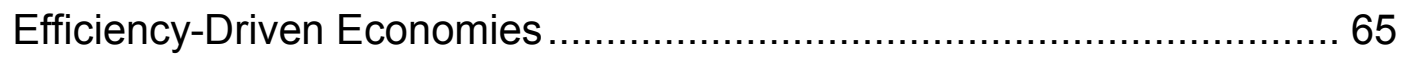

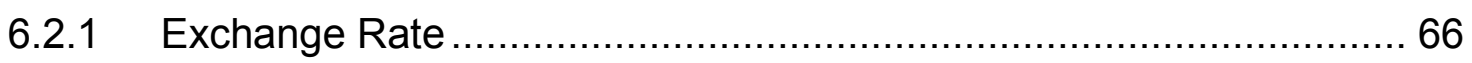


6.3 Hypothesis Two: Improvements in Export Growth Lag Currency Depreciation in Efficiency-Driven Economies

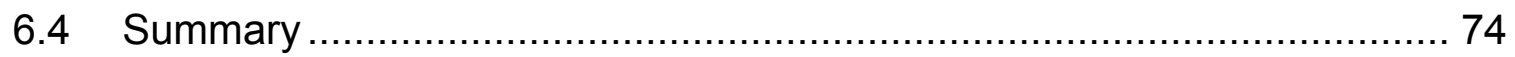

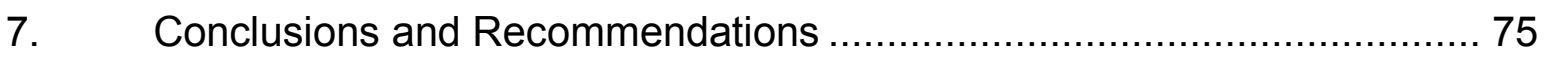

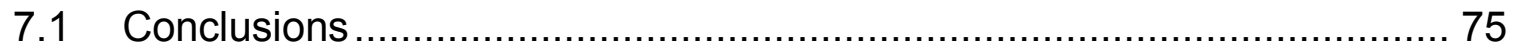

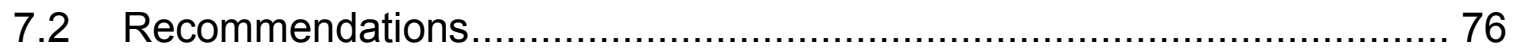

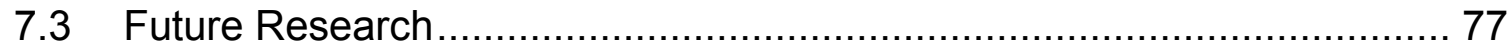

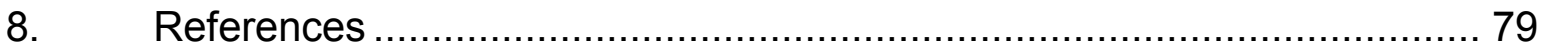

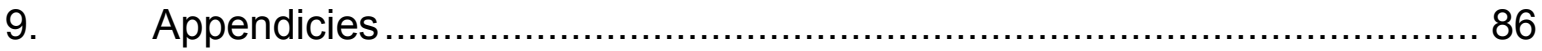

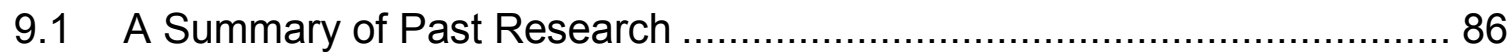

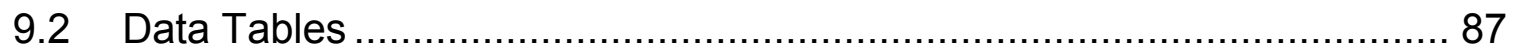




\section{List of Figures}

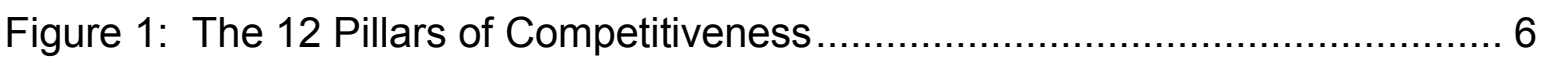

Figure 2: Export Growth by Country ........................................................... 46

Figure 3: Export Growth by Year (1990 to 2009).............................................. 48

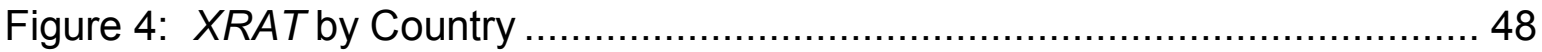

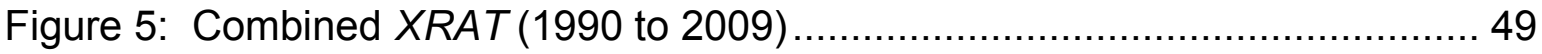

Figure 6: Scatterplot of Export Growth and XRAT with a Linear Regression Line

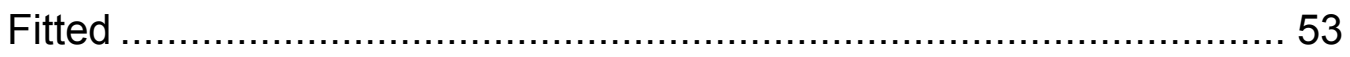

Figure 7: Scatterplot of Country Export Growth and XRAT with a Linear Regression Line Fitted ........................................................... 54 


\section{List of Tables}

Table 1: Classification of Specific Exchange Rate Arrangements ..................... 12

Table 2: List of Economies at Each Stage of Development. ............................. 37

Table 3: Weights of the Three Main Sub-Indexes at Each Stage of Development37

Table 4: Efficiency-Driven Economies........................................................... 40

Table 5: Sample of Efficiency-Driven Economies.......................................... 41

Table 6: Average Annual Export Growth (1990 to 2009).................................. 47

Table 7: Percentage by which the Currency has Depreciated against the US Dollar

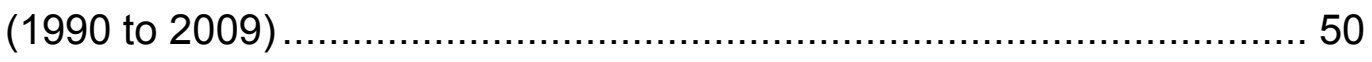

Table 8: Percentage by which the Currency has Depreciated against the US Dollar

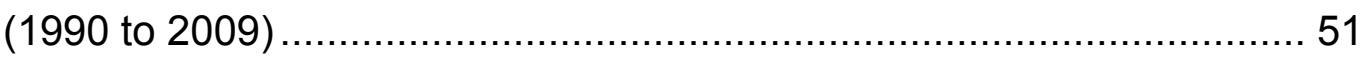

Table 9: Fixed Regression Results for the Effect of XRAT and Country on Export

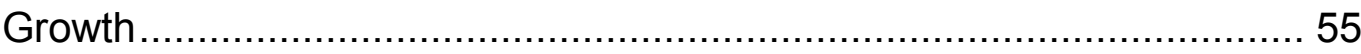

Table 10: Fixed Regression Results for the Effect of XRAT, GDP and Country on

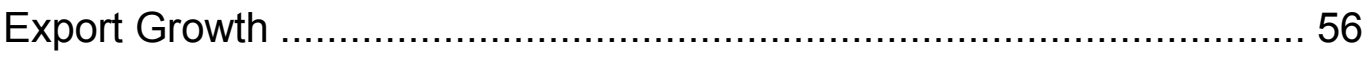

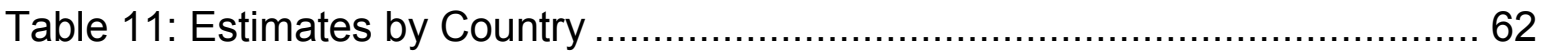




\section{List of Abbreviations}

ECLAC Economic Commission for Latin America and the Caribbean

GDP Gross Domestic Product

GNI Gross National Income

IFS International Financial Statistics

IMF International Monetary Fund

SDR Special Drawing Rights

US United States 


\section{Introduction to the Research Problem}

\subsection{Research Title}

Exchange rate policy and export performance in efficiency-driven economies

\subsection{Research Problem}

Current global market conditions, where many economies are undergoing a period of financial strain or recession, have brought to prevalence the concept of a 'currency war' or, less dramatically, competition based on exchange rate weakness (Ahamed, 2011). According to Dolan (2010), certain world economies are investigating pegging or weakening their exchange rates to gain global export market share through price competitiveness. Many economies have become more dependent on exports due to slow domestic growth and a relative, weaker exchange rate would allow export goods to become more competitive (Kaiser \& Wroughton, 2010).

While the concept of a 'currency war' may have been given recent attention, it is not a new debate. Prebisch $(1950,1964)$ demonstrates this in a shift in early thinking on economic growth and development. Inward-looking strategies (Prebsich, 1950), where reliance was placed on a home market for manufactured goods in a process of import substitution, were initially preferred by countries in Latin America and Sub-Saharan Africa (Keesing, 1967). Outward-looking strategies were later given preference by many developing economies, in particular 
those in Asia, as manufactured export industries were seen as a key component of industrial development and economic success (Keesing, 1967).

Prebisch (1964) further developed the argument in support of export-oriented industrialisation as a key component for economic growth. Such economic growth could be achieved through an expanded export market share achieved via comparative cost advantages, such as cheap labour, or exchange rate weakness (Prebisch, 1964; Keesing, 1967). In time, most economies have shifted to outward-looking strategies of export promotion (Dollar, 1992).

Currency weakness, or a weakening of the exchange rate, to achieve price competitiveness could be achieved either through devaluation, in the instance of a fixed exchange rate arrangement (Todaro \& Smith, 2009), or depreciation due to free-market operations, consistent with the concept of a floating exchange rate (Krugman \& Obstveld, 1997). Prebisch (1964) held that exchange control and currency depreciation were a means to boost export performance. It is in such early economic arguments that the concept of a 'currency war', or competing on the basis of relative currency weakness for price competitiveness, emanated.

Currency weakness, therefore, may be viewed by many developing economies, pursuant of a strategy of export-led growth, as favourable (Owen, 2005). This follows from the argument that a weaker home currency would reduce the price of exports making them cheaper in comparison to competitors within the export 
market (Mussa \& Rosen, 1978; Auer \& Chaney, 2009). Economic growth follows, as a greater demand for exports would encourage higher domestic production and in so doing, boost employment and adjust the trade balance in favour of the 'weakening' currency. According to this argument, the net effect would be to boost gross domestic product (GDP) and raise domestic income and incomes per person (Owen, 2005). Such a theory, in isolation, appears plausible. In reality, however, there are a number of other factors which impact any competitive advantages as a result of currency weakness in developing nations, as well as in developed nations (Boltho, 1996).

Boltho (1996) explores these factors, which include an unpredictability of depreciation effects; an inability to affect real exchange rates; wage inflation; price inflation; and a negative long-run impact on price competitiveness (Boltho, 1996). One of the oldest criticisms of currency depreciation is 'elasticity pessimism' (Boltho, 1996). If price elasticities of demand for exports and imports are low and the Marshall-Lerner condition for an effective depreciation are not fulfilled, 'the exchange rate instrument behaves perversely' where the currency may overshoot its equilibrium level (Boltho, 1996, p. 7). The Marshall-Lerner condition assumes balanced trade at the outset of currency depreciation and a full pass through from depreciation to import and export prices (Caves, Frenkel, \& Jones, 1990). Despite these factors, a focus on currency depreciation is still viewed as a viable option (Boltho, 1996). 


\subsection{The Scope of the Research}

The argument of weakening a currency to gain global export market share through price competitiveness is most relevant for developing countries which experience, or aim to achieve, substantial industrial growth that is fuelled by exports (Clark, 1996). The so called efficiency-driven economies, as defined by Porter (1998) and described in the World Economic Forum Global Competitiveness Report 20102011 (Schwab, 2010), are developing, industrialising nations for whom export sectors are a key contributor to economic advance.

Efficiency-driven economies, however, are not a recent concept. More than half a century ago the economists Rostow (1960) defined five stages of economic growth. These stages included traditional society, preconditions for take-off, takeoff, drive to maturity and age of high mass consumption (Rostow, 1960). Take-off was the third stage of economic growth, which was characterised by self-sustained growth supported by the development of significant manufacturing industries (Rostow, 1960). Porter (1998) provides a 'modern rendition of Rostow’s typology by identifying three stages of development (as opposed to growth): a factor-driven stage, an efficiency-driven stage and an innovation-driven stage, to which he adds two transitions' (Acs \& Autio, 2011, p. 1). Factor-driven economies compete based on their 'factor endowments: primarily unskilled labour and natural resources'; whereas innovation-driven economies compete on the basis of sophisticated production processes and innovation to produce new and different goods (Schwab, 2010, p. 9) 
The efficiency-driven stage of development, as defined by Porter (1998), is comparable to the take off stage of growth (Acs \& Autio, 2011). Countries in the efficiency-driven stage of development require focus on efficiency enhancers within their home economy (Schwab, 2010). Efficiency enhancers include improvements in goods and labour market efficiency; gains in market size; financial market development; technological readiness; and higher education and training (Figure 1). Countries in such a stage of development are particularly relevant to this study as the strong outward, export orientation renders them most sensitive to currency movements (Boltho, 1996). Outward focus is not unimportant to factor-and innovation-driven economies, however, it is most relevant to efficiency-driven economies which focus on export-oriented industrialisation in support of economic growth (Schwab, 2010). 
Figure 1: The 12 Pillars of Competitiveness
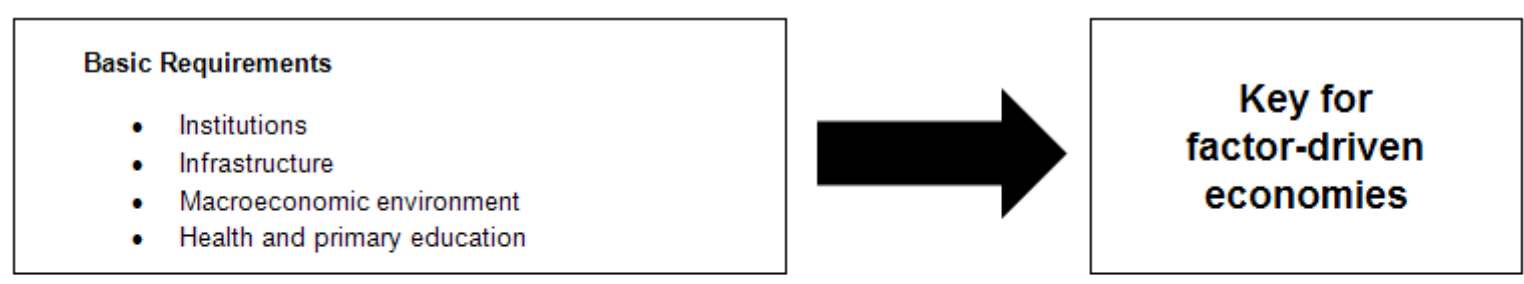

Efficiency enhancers

- Higher education and training

- Goods market efficiency

- Labour market efficiency

- Financial market development

- Technological readiness

- Market size

Innovation and sophistication factors

- Business Sophistication

- Innovation
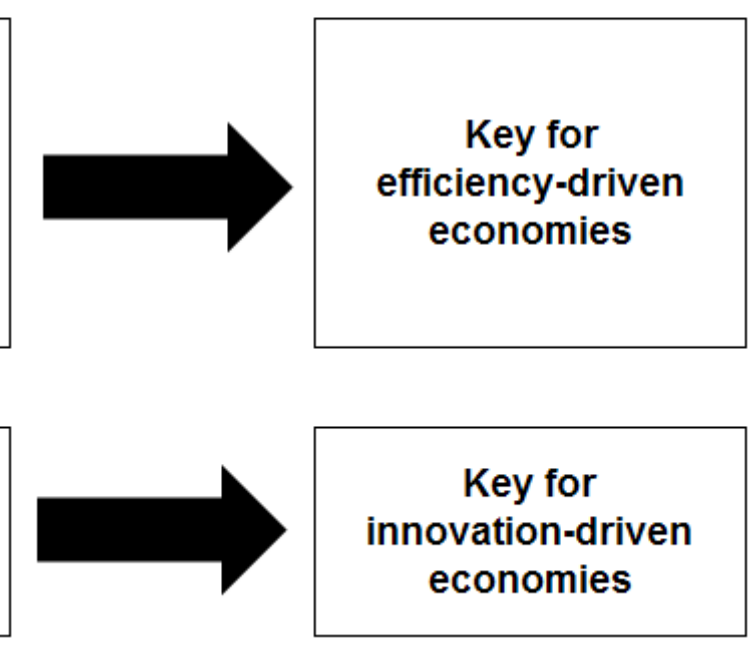

Source: (Schwab, 2010)

When a country has an efficient goods market, it is competitively positioned to produce the desired mix of goods and services and ensure that they are effectively traded in the global economy, dependant on the particular economy's factor conditions (Schwab, 2010). In turn, such focus facilitates the development of more efficient production processes and increases product quality (Schwab, 2010) in support of an economy's export orientation and global competitiveness (Econometrix, 2011).

Previous studies on the relationship between currency weakness and export performance provides inconclusive, and sometimes contradictory, evidence. 
Research done by Bautista (1982), Abeysinghe and Yeok (1998), Musila and Newark (2003) and Auer and Chaney (2009) found that currency weakness improves export performance. However, contrary findings were presented in studies done by Lizondo and Montiel (1989), Calvo and Reinhart (2000), Musila (2002), Frankel (2005) and Berman and Berthou (2009), where currency weakness was found to have either a negative effect on export performance, or little effect.

Many of these studies reviewed a small sample of developing or developed countries with a particular focus on fixed exchange rate regimes due to the historic prevalence of fixed exchange rates under the Bretton Woods system (Dooley, Folkerts-Landau, \& Garber, 2004). In addition, many of these studies focussed on short-run analysis, and did not emphasise the effects of currency movement in the longer run. To address this shortcoming, this study focuses on floating exchange rate regimes across a relatively large sample of countries, with reference to the effects of currency weakness on export performance over a longer time frame.

\subsection{Research Aim}

The purpose of this research is to establish the impact that currency weakness has on export performance with particular focus on efficiency-driven economies with floating exchange rate arrangements. An improved understanding of this relationship would provide policymakers and economic advisors with a greater 
depth of knowledge upon which to make decisions to 'restore economic equilibrium to a nation' (Owen, 2005, p. 99).

In answering the central research question, two main objectives were identified for this research. These objectives comprise an assessment of whether export performance is improved by currency depreciation in efficiency-driven economies; and an evaluation of whether improvements in export growth lag currency depreciation in efficiency-driven economies. 


\section{Literature Review}

\subsection{Introduction}

Country competitiveness is the extent to which a country is capable of generating wealth, when measured against other countries, in world markets (Shenkar \& Yagong, 2010). To be competitive, it is necessary for government to foster and promote an environment that favours business operations and productivity in one or more industries. Productivity does not necessarily come from what a country has, but from what it uses those resources to achieve or produce (Sekkat, 2009). Many view a country's currency as one of those resources and perceive the relative strength or weakness thereof as a contributing factor to the country's competitiveness (Berman \& Berthou, 2009).

In this vein, the Economic Commission for Latin America and the Caribbean (ECLAC) (2007) views international competitiveness as the ability of a country's firms and producers to capture and maintain market share and incomes on regional and international markets. Export market share or export performance, a manifestation or outcome of such rivalry or competitive behaviour, provides a proxy or barometer for competitiveness (Durand \& Giorno, 1987; Bautista, 1982; Poon, 1994). This study adopts this convention as the basis for assessing competitiveness.

Export performance therefore requires further understanding. Similarly, if the relationship between currency weakness and export performance is to be 
understood within the context of efficiency-driven economies, currency weakness and its impact on price competitiveness, as well as the concept of efficiency-driven economies, require further explanation. Hence three distinct categories of theory have been presented within this Section: currency weakness; export performance; and efficiency-driven economies.

First, currency weakness is discussed; this includes an exploration of exchange rate arrangements and the manner in which currencies may weaken. Second, export performance is reviewed with a discussion regarding an aggregate level of analysis. Clarity on the concepts supportive of export performance is also provided. Third, efficiency-driven economies and the characteristics pertaining thereto are discussed. This provides the basis for considering the link between currency weakness and export performance which has been explored. Studies that confirm and contradict this relationship have been examined; with a view to assessing the theoretical and empirical literature that deals with this relationship in efficiency-driven economies.

\subsection{Currency Weakness}

\subsubsection{Nominal and Real Exchange Rates}

The nominal exchange rate is the officially quoted exchange rate. However, this nominal rate does not account for effective purchasing power of a currency (Colander, 2010). The real exchange rate, by contrast, accounts for purchasing 
power, as it is adjusted for differences in price levels and different rates of price inflation (Colander, 2010).

Where depreciation in the nominal exchange rate is offset by increased domestic price inflation, the real exchange rate may remain unchanged (Bird, 1983). In such instances, the potential export price competitiveness advantages of currency weakness would be offset by domestic price inflation (Bird, 1983). Burstein, Eichenbaum, and Rebelo (2004) and Owen (2005) argue that the real exchange rate provides a more accurate representation of the effective exchange rate, as it accounts for changes in purchasing power.

\subsubsection{Exchange Rate Arrangements}

The International Monetary Fund (IMF) defines an exchange rate arrangement as the manner in which a country's currency operates (IMF, 2008). Exchange rate arrangements may differ according to the degree of control a country has over its currency and whether a formal or informal commitment to the exchange rate path has been made (Calvo \& Reinhart, 2000). Using the IMF's classification scheme as shown in Table 1, exchange rates may be broadly classified into two types of exchange rate arrangements: fixed and floating. 
Table 1: Classification of Specific Exchange Rate Arrangements

\begin{tabular}{|l|l|}
\hline Specific exchange rate arrangement & Broad classification \\
\hline Exchange arrangement with no separate legal tender & Fixed \\
\hline Currency board arrangement & Fixed \\
\hline Fixed peg arrangement & Fixed \\
\hline Pegged exchange rate within horizontal bands & Pegged floating \\
\hline Crawling peg & Pegged floating \\
\hline Crawling band & Pegged floating \\
\hline $\begin{array}{l}\text { Managed floating rate with no pre-determined path for } \\
\text { the exchange rate }\end{array}$ & Floating \\
\hline Independently floating & Floating \\
\hline
\end{tabular}

Source: (IMF, 2008)

A floating exchange rate is determined by free market forces of demand and supply (Owen, 2005). In contrast, a fixed or pegged exchange rate is one set by government or central bank policy (Bautista, 1982). A fixed exchange rate may be associated with a basket of currencies or a currency, such as the United States (US) dollar; or maintained by the central bank within a particular price range relative to another currency or currency basket (Owen, 2005).

Many developing economies have been encouraged by the IMF and the World Bank to adopt policies of floating exchange rates to facilitate price corrections and promote export led growth (Musila \& Newark, 2003). Historically, however, with the legacy of the fixed-rate Bretton Woods system (Dooley et al., 2004), some reluctance amongst policy makers to relinquish control over the exchange rate has been experienced. This 'fear of floating' (Reinhart, 2000, p. 65) may emanate from uncontrollable changes to the exchange rate due to market forces, to which a floating exchange rate exposes an economy (Millman, 1990). 
Reinhart (2000, p. 65) argues that the 'official labels' of a country's exchange rate arrangement do not always provide an adequate representation of actual country practice. A country may officially commit to an exchange rate arrangement. However, practice may deviate from the arrangement to which a country's policy makers have committed. Regardless of whether an exchange rate path has been committed to by a country, the de facto exchange rate arrangement provides a more realistic representation thereof. In a similar approach to several authors cited by Edwards (2011), the de facto exchange rate will be used for purposes of this study (IMF, 2008). Based on the de facto exchange rate arrangement in evidence, the mechanics by which a currency may weaken differ: devaluation or depreciation.

\subsubsection{Devaluation versus Depreciation}

Owen (2005, p. 1) states that the relative value of a currency can be reduced through either depreciation or devaluation'. Currency depreciation is usually the result of free-market operations to achieve a reduction in currency value, consistent with the concept of a floating exchange rate (Krugman \& Obstveld, 1997). Currency devaluation is a more conscious event. It is normally the result of a policy decision, whereby a country's official exchange rate is reduced relative to all other currencies (Todaro \& Smith, 2009).

A weakening exchange rate, in the absence of price inflation, decreases export prices measured in home currency relative to other currencies (Junz \& Rhomberg, 1973). This decrease in export prices renders goods more affordable, and thus 
more competitive from a price perspective (Junz \& Rhomberg, 1973). Such price competiveness is viewed as a favourable effect of currency weakness (Owen, 2005).

A reduction or weakening in an exchange rate, however, may have many other consequences, such as price inflation (Todaro \& Smith, 2009). Price inflation is caused by rising aggregate demand as a result of lower export prices and higher import prices (Todaro \& Smith, 2009). If the economy is at full employment, prices are pulled upwards as consumers buy fewer imports and foreigners increase their demand for cheaper exports (Todaro \& Smith, 2009). Kamin and Rogers (2000) argue that price inflation is a real risk should the real exchange rate be weakened or targeted on a sustained basis.

These consequences, positive and negative, are far more significant for developing or emerging-market economies (Bautista, 1982). Most importantly, this is because developing economies would find their exports more competitively priced in a global market with a weaker currency (Mussa \& Rosen, 1978). Reinhart (2000), however, argues against a weakened currency as the majority of emerging-market debt, in the government and private sectors, is denominated in hard foreign currency. A home currency that is worth less, relative to the foreign currency in which the debt is denominated, makes it far more expensive to service the debt. In addition, Boltho (1996) claims that the effects of a weakened currency on price elasticities and the real exchange rate are not perfectly predictable for policy makers. Further, wage inflation may also be imported with a weakened home 
currency, as workers may seek wage increases to protect the real purchasing power of their incomes in the face of price inflation (Owen, 2005).

Any competitive advantage conferred by currency weakness may further deteriorate where a number of economies experience currency weakness simultaneously (Liaquat, 2011). Liaquat (2011) examines evidence of this from the 1930s, where many countries pursued export led growth via price competitiveness by weakening their currencies. Such a simultaneous approach created turmoil in the foreign exchange markets and rendered the whole approach 'self-defeating' (Liaquat, 2011, p. 97).

Boltho (1996), however, also offers the view that a weakened currency may confer a semi-permanent competitive advantage. Under a floating exchange rate regime, currency depreciation may result in a temporary increase in sales (Boltho, 1996; Clark, 1996). However, such advantage may be sustained. Arrow (1963, p. 155) develops the view of the 'production function as an expression of technical knowledge' with the addition of growing human knowledge over time and through repetition, a concept known as 'learning by doing'. One of the ways in which industrial and efficiency-driven firms gain competitiveness would be to move down the cost curve by accumulating hours of experience (Arrow, 1963; Keesing, 1967). Berman and Berthou (2009, p. 103) furthers this argument, stating that 'a real depreciation of the exchange rate would increase the volume of exports'. However, Berman and Berthou (2009) argue the extent and duration of such an increase is indeterminate. 
Junz and Rhomberg (1973) show that the effects of price competitiveness, achieved through a depreciated currency, may take as long as one year to eighteen months to present themselves. An increase in export market share may lag currency weakness due to a number of lag effects (Junz \& Rhomberg, 1973). These lag effects include a recognition lag, whereby it takes buyers time to recognise price competitiveness; decision lag, as it takes time for new orders to be placed; delivery lag, as trade flows are recorded upon receipt of payment which may be delayed due to credit terms of trade; replacement lag, as buyers may need to use up existing inventories before ordering replacement stock; and production lag, as export manufacturers take time to increase production to meet enhanced demand (Junz \& Rhomberg, 1973). This study therefore seeks to understand better the longer-run effects of currency depreciation on exports to ascertain whether significant competitive advantage is inferred in the short run and sustained in the long term.

\subsection{Export Performance}

\subsubsection{Aggregate Data}

Within the discipline of economics, macroeconomics has a primary focus of economic activities at a national level (Tregarthen \& Rittenberg, 2000). It then follows that economic analyses at a national level require data that represent aggregate values of economic activity (Owen, 2005). Kamin and Rogers (2000) show that real exchange rate depreciations boost aggregate demand across an economy via export growth and a substitution from imports to domestic goods. 
Bird (1983, p. 474) argues further that currency depreciation induces relative price changes at an aggregate level and is insufficiently selective in its effects as it 'fails to discriminate between individual sectors or industries'. As currency weakness has a holistic impact on a nation's economy, and currency depreciation or a devaluation event is not experienced in isolation by a few industries, export performance at a national or aggregate level will be reviewed here.

\subsubsection{Export Quantity}

Export performance has demand- and supply-side effects which may result from currency weakness (Owen, 2005). From a demand perspective, buyers of an economy's exports must be considered, and competition is in many instances based on price (Razmi, 2007). Currency depreciation involves a 'positive competitiveness effect' as it may 'induce an increase in world demand for domestic goods, following a decrease in domestic relative prices' (Berman \& Berthou, 2009, p. 107). However, Razmi (2007, p. 462) states that in instances where developing countries target high-income markets, increased price competition due to a weakening currency may 'lead to high-income country protectionism' which may include pressure to re-align exchange rates.

Elasticity of export demand may influence the impact of currency weakness on the price competitiveness of exports (Bird, 1983). Where export product prices are quoted in domestic currency, the greater the elasticity of demand for an export 
product, the greater effect currency weakness shall have on export demand (Bird, 1983). Where the price of export products is quoted in foreign currency, export elasticity of demand is largely irrelevant as depreciation does not effectively reduce the product price and enhance price competitiveness (Bird, 1983).

However, invoicing currency may determine 'whether exchange rate fluctuations lead to a switching of demand between goods produced in different countries' (Goldberg \& Tille, 2010) due to preferences for exchange rate risk. The US dollar has been extensively used as the invoicing currency for global transactions (Goldberg \& Tille, 2010). Thus, the relative strength or weakness of a home currency to the US dollar may further impact the effect of a depreciated home currency on export growth.

Similarly, currency depreciation may lead to detrimental supply-side effects. Supply-side effects are concerned with an economy's ability to produce and supply exports (Owen, 2005). These include labour, infrastructure, technological capability and business funding. Currency weakness may induce a balance-sheet effect where firm's production capability and ability to compete in the export market is reduced (Berman \& Berthou, 2009). As the home currency is worth less, firm's ability to fund inputs into production may be reduced as a result. The focus of this study is on market-clearing quantity exported. 


\subsubsection{Export Growth}

Prebisch (1964) proposed outward-looking strategies to support economic growth, primarily in developing economies. Such strategies seek to overcome the constraints of a home economy in the development of export-oriented industrialisation (Prebisch, 1964). Export performance or growth in export market share that may result, is then seen to be supportive of economic growth (Keesing, 1967; Svedberg, 1991). Bautista (1982, p. 354) supports this argument and claims that 'superior export performance' is empirically associated with 'superior economic performance', particularly amongst developing, industrialised economies.

As an aside, export performance is a complex variable to define and measure (Lages, 2011), as it has financial and non-financial measures and may be operationalised and conceptualised in many different ways. There are internal and external factors that may impact on export performance (Lages, 2011). Internal factors include firm characteristics and competencies, product characteristics and management characteristics (Donthu \& Kim, 1993); whereas external factors comprise industry, foreign and domestic market characteristics (Diamantopoulos \& Inglis, 1988). Econometrix (2011) argues that it is a combination of these factors, that leverage off fundamental productivity, factor endowments and demand from abroad, and lead to increased export performance.

An increase in export performance could be seen in an increase in export market share (Durand \& Giorno, 1987); export growth (Sousa, 2004) or an improved 
balance of trade (Santos-Paulino, 2002) which refers to net exports, or the difference between exports and imports for a country (Musila \& Newark, 2003). Sousa (2004) shows that export growth is one of the most prevalent indicators of export performance in the review of 43 empirical studies on export performance published between 1998 and 2004. In this vein export growth, indicative of increased market share, shall be used as a measure of export performance in this study.

Export growth rates are sensitive to the choice of initial year in any study, as certain countries may start from a low base (Balassa, 1978). Improvements in export performance may thus appear inflated should measurement commence off a low base (Balassa, 1978). Balassa (1978) thus suggests the use of a longer time period over which the study is conducted to mitigate such effects. In addition Owen (2005) argues that due to the lag effect of price changes on export performance, as discussed earlier, measurement should be in years not quarters. Such an approach, using annual data over a longer period of time, shall be adopted here.

\subsection{Efficiency-Driven Economies}

\subsubsection{Developing Economies}

Developing economies are those economies which, relative to their population, have not yet achieved significant industrialisation (Dollar, 1992). V Vadlamannati \& Tamazian (2009) state that the majority of developing economies have a medium 
to low standard of living, with a strong correlation between low income and high population growth.

The World Bank (2010a) classifies developing economies as low-and middleincome countries. Low-and middle-income countries are defined as those countries with gross national income (GNI) per capita of less than \$11 906 in 2008 (World Bank, 2010a). Classification by income does not, however, accurately reflect the development status of an economy. The World Bank (2010a) thus regards such classification as convenient.

The IMF (2009) provides further characteristics to define developing economies. Such characteristics include export diversification; degree of integration into the global financial system; per capita income; infrastructure development; openness of the market economy; and industrial growth (IMF, 2009). Poon (1994) argues that export promotion is essential to countries in such a stage of development, as it enables them to overcome a limited domestic market.

However, not all developing economies progress at the same rate (Schwab, 2010). Certain developing economies, such as Brazil and Malaysia, which aim to achieve substantial industrial growth fuelled by exports (Clark, 1996) have developed a level of infrastructure and an open market economy to support this. Efficiency driven economies constitute such a set of economies. Efficiency-driven economies have an upper GDP limit of $\$ 9000$ per capita (Schwab, 2010) and thus fall into the 
broad classification of developing economies (Clark, 1996). This follows from the argument that GNI is regarded as GDP combined with income obtained from other countries, such as dividends and interest (Tregarthen \& Rittenberg, 2000). Tan and Phang (2005, p. 3) further this concept as efficiency-driven economies are underpinned by 'efficiency infrastructure'. Such infrastructure facilitates the efficient running of an economy, such as transportation and telecommunications infrastructure, and further supports the economy's export orientation (Tan \& Phang, 2005).

\subsubsection{Export Orientation}

Against this backdrop, efficiency-driven economies (Schwab, 2010) are developing economies which experience industrial growth, fuelled by exports (Clark, 1996). Supported by an open market economy, efficiency-driven economies seek to overcome the constraint of a limited domestic market in the export market (Baldauf, Cravens, \& Wagner, 2000). Such an outward-looking strategy is intended to support export-oriented industrialisation and economic growth (Prebisch, 1964).

Balassa (1978) argues that an export-oriented growth is preferable for developing economies in a phase of industrialisation. Such a focus leads to more efficient resource allocation, greater capacity utilisation, increased employment, and technological enhancements (Balassa, 1978). These improvements and advances are thus in the category of efficiency enhancers, which is defined as an important area of development for efficiency-driven economies (Schwab, 2010). Efficiency 
enhancers include improvements in goods and labour market efficiency; gains in market size; financial market development; technological readiness; and higher education and training (refer Figure 1).

Acs, Desai, and Hessels (2008) state that efficiency-driven economies are characterised by large markets which exhibit efficient production practices which allow for economies of scale. Porter (1998) argues that such economies have a strong export orientation to support such economies of scale. In addition, large firms and multinationals are the primary drivers of exports derived mainly from manufacturing industries (Porter, 1998). The development of substantial manufacturing export industries in such developing countries, however, has been a recent development. The Prebisch-Singer hypothesis (Bloch \& Sapsford, 2000), based on a historic predominance in the 1950s of primary good exports from developing countries and industrial imports from developed countries, showed a deterioration in the terms of trade for developing countries in their dealings with developed countries. Recent developments in trading patterns have seen dramatic increases in exports of industrial goods from developing countries (Bloch \& Sapsford, 2000), such as the efficiency-driven economies, which allow for an improvement in the terms of trade and enhanced price competitiveness.

\subsection{Currency Weakness and Export Performance}

An examination of the literature that reviews the relationship between currency weakness and export performance provides mixed evidence. Appendix 9.1 
provides a comparative table of these studies. Early studies on 'currency wars' emanate from the work of Prebsich (1964). Prebsich held that currency depreciation was a means to boost export performance through price competitiveness (Prebisch, 1964). More recently, Todaro and Smith (2009) state that a nation can improve the competitive position of its goods in international markets by reducing the price of its home currency. However, the effects of currency weakness on export performance are not always found to be positive.

In a study on Malawi performed using time-series data from 1968 to 1998, Musila (2002) found currency devaluation to worsen export performance in the short run, and only marginally improve it in the long run. The predominant focus of this study, however, was in the short run (Musila, 2002). According to Calvo and Rienhart (2000) exports do not initially increase after devaluation in an economy's currency. This research, which covers 39 countries for the period January 1970 to November 1999, shows that exports decline for the first eight months at least after a devaluation in home currency (Calvo \& Reinhart, 2000). This decline is caused by a variety of factors, including corporate financial distress, the absence of trade credit and increased costs of imported inputs into export production (Calvo \& Reinhart, 2000). Frankel (2005), Berman and Berthou (2009), and Lizondo and Montiel (1989) agree, with the finding that exports rebound only moderately, back to initial levels in the long-run.

Berman and Berthou (2009) found the impact of currency depreciation on exports to be less positive, or even negative, in 27 developed and developing countries 
over the period 1990 to 2005 . This study found this negative relationship to be particularly prevalent when the magnitude of the currency devaluation or depreciation was large; and financial market imperfections, such as foreign currency denominated borrowings and credit constraints, were in existence (Berman \& Berthou, 2009).

Bautista (1982) found in a study of 23 developing countries between 1973 and 1979 that currency depreciation, regardless of magnitude, did not lead to a permanent improvement in export competitiveness for the majority of the sample reviewed. Small, incremental exchange rate changes were found to improve export performance more than 'large, once-and-for-all devaluations and those under a crawling peg regime' (Bautista, 1982, p. 372). However, improvements resulting from the afore-mentioned small, incremental changes were found to be marginal (Bautista, 1982).

Auer and Chaney (2009), however, found a more positive association where a depreciation of the real exchange rate caused exporting firms to increase export volumes. Edwards (2011, p. 1) argues that a 'relatively stable real exchange rate, that does not become overvalued, is a key component of outward-oriented, export based development strategies'. This is seen in the case of China, which has effectively promoted exports by deliberately maintaining an undervalued exchange rate (Edwards, 2011). 
Contrary to earlier findings, a simulation analysis performed by Musila and Newark (2003, p. 339) on Malawi covering the period 1967 to 1996 found that 'devaluation helps to improve export performance and to curtail the growth of imports in the long run'. This simulation analysis uses a small, open economy as a proxy to determine the sensitivity of imports, exports and trade balance variables to nominal exchange rate devaluation (Musila \& Newark, 2003). Musila and Newark (2003) applied a shock to the model, equivalent to the 30 percent devaluation of the Malawian kwacha, to simulate the impact of currency movement on trade balance. Such mixed findings in two studies involving Musila (Musila, 2002; Musila \& Newark, 2003) performed one year apart, must be attributed to different methods utilised as well as a distinct focus on the short run in 2002 and the long run in 2003.

Abeysinghe and Yeok's (1998) study of Singapore between 1980 and 1995 concurs with this view. Abeysinghe and Yeok (1998) cite several authors finding that for small open economies, exchange rate depreciation encourages exports. This study, however, does not conclusively demonstrate increased export performance, merely encouragement thereof.

Regardless of whether improvements in export performance are experienced as a result of currency weakness, certain unintended consequences may occur. Abeysinghe and Yeok (1998) argue that the greater the proportion of imported inputs into export production, the lesser the impact of currency weakness on export performance. Profit margins effectively narrow to maintain price competitiveness in 
such instances (Abeysinghe \& Yeok, 1998). Reduced profitability may then negate the benefits of export market share growth.

Fears also exist that any increase in export performance may not cover the additional costs incurred due to the effect of currency depreciation on import costs (Musila \& Newark, 2003). Further, Clark (1996) found that, in the case of sensitive export products, an importing country may consider the erection of protectionist barriers to counteract the effects of significant currency devaluation and apply pressure for a revaluation.

\subsection{Implications}

Previous research provides a lack of conclusive evidence indicating causality between currency weakness and improved export performance. There is a general agreement in the literature that currency weakness does impact export performance via the mechanism of price, however direction, extent and duration of the impact were not always conclusive. Given recent attention on the concept of competing on the basis of currency weakness, this relationship required further exploration.

The economies reviewed as part of previous studies appear convenient and random in their selection. Few studies defend the choice of population and sample. Small samples were also noted in the instance of Mohamad (2008) where a sample of four Southeast Asian economies was reviewed; Owens (2005) studied 
Malaysia, Korea and Chile; and Abeysinghe and Yeok (1998) isolated their research to Singapore. A more relevant population shall be reviewed as part of this research. Efficiency-driven economies are considered more relevant as they are developing economies which aim to achieve a substantial industrial growth fuelled by exports (Clark, 1996).

Much of the research referred to a number of independent variables and failed to isolate the relationship between currency weakness and export performance clearly. In addition, previous studies focussed on economies with a fixed exchange rate arrangement and little work has been done on the floating rate economies. This research focussed on the relationship between currency weakness in floating rate efficiency-driven economies and export performance. 


\section{Research Questions}

\subsection{Introduction}

Given the literature review above, research objectives have been developed. The first involves attempting to understand whether currency depreciation improves export performance in efficiency-driven economies; and the second, to ascertain if there is a lag in the improvement effect of currency depreciation on export performance in efficiency-driven economies. Hypotheses have been developed from these research objectives and the literature review in order to assess the impact of currency depreciation on export performance in efficiency-driven economies.

\subsection{Research Hypotheses}

H1: Export growth is improved by currency depreciation in efficiency-driven economies.

H2: Improvements in export growth lag currency depreciation in efficiency-driven economies.

No hypotheses have been specified to address the impact of currency weakness or depreciation on imports in efficiency-driven economies. 


\section{Research Method}

\subsection{Research Design}

For this study, quantitative causal research has been undertaken. This follows from the need to determine the impact of one variable on another (Blumberg, Cooper, \& Schindler, 2008). In this research, the impact of currency depreciation on export growth is under investigation.

Explanatory variables that contribute to the understanding of this relationship have therefore been identified. Currency and world income have been used as the independent variables (Blumberg et al., 2008) to indicate the purchasing capacity of the international community (Owen, 2005). Annual changes in world gross domestic product are used as a proxy for growth in world income (Owen, 2005). All other economic factors which may impact export performance have been held constant in an attempt to isolate the impact and influence of currency weakness on export performance (the dependant variable) (Blumberg et al., 2008).

Such an approach is in line with existing frameworks utilised by several researchers testing the effects of currency weakness on export or trade balance performance. These studies (refer Appendix 9.1) have largely adopted either panel data models (Berman \& Berthou, 2009; Santos-Paulino, 2002); or undertaken time series analysis (Owen, 2005). Musila and Newark (2003) examine four empirical approaches to such research. Such approaches include a 'before-and-after' approach, which examines changes in the trade balance at the 
time of devaluation; a control group approach, where a sample of devaluing countries are compared to a control group of non-devaluing countries; a time series approach; and a macro-simulation model (Musila \& Newark, 2003). Several authors are cited regarding all four approaches. However, predominant support is in favour of time series and simulation models.

Poon (1994) contrasts cross-sectional models and time series models for the purposes of such a study. Time series models for individual countries tend to portray a more accurate representation of the relationship, yet have difficulties in representing the lag structure between exports and currency weakness (Poon, 1994). In contrast, cross-sectional analysis assumes similar structural and behavioural relationships for all countries within the sample and offers a high level generalisation of the relationship (Poon, 1994). Panel data models comprise cross-sectional and time series dimensions (Dougherty, 2006). They allow for a larger number of observations to be considered whilst providing for country-specific and time-specific effects and a more accurate representation of a lag structure (Dougherty, 2006; Santos-Paulino, 2002). Given the hypotheses formulated, a panel data model is considered to be most appropriate for purposes of this study.

There are three models that can be used for analysing panel data. The first model, referred to as pooled least squares, combines time-series and cross-sectional data, assuming a common intercept (Mohamad, 2008). The underlying model is then estimated using ordinary least squares which allows for the estimation of unknown parameters. This model assumes a constant intercept and slope, which 
Mohamad (2008) argues is unreasonable for such research as intercepts and slope may vary.

The second model recognises that omitted variables may lead to changes in the time-series and cross-sectional intercepts (Bond, 2002). This fixed-effects model allows for intercepts to be different for different cross-sections (Santos-Paulino, 2002). The third, random-effects model, allows for variation in cross-sections as well as the periods (Mohamad, 2008). Use of the fixed-effects model is preferred for such research on this topic (Santos-Paulino, 2002; Mohamad, 2008). A similar approach has been used here as it allows for cross-sectional variation, whilst a fixed time period is maintained.

A model for the export function, as shown by Owen (2005) and Mohamad (2008) is:

$$
y_{\mathrm{it}}=\alpha_{\mathrm{it}}+\beta_{\mathrm{i}} x_{\mathrm{it}}+\varepsilon_{\mathrm{it}}
$$

where, $i(i=1, \ldots n)$ is the cross-section units (countries) and $t(t=1, \ldots \mathrm{T})$ is the periods. The dependant variable $y$ measures the export function; the vector $\beta$ is the parameter of interest; and the residual is denoted by $\varepsilon$. The design matrix $(\mathcal{X})$ for the model is as follows:

$$
x=[X R A T, G D P]
$$


$X R A T$ is the country's annual average exchange rate to the US dollar defined such that an increase in XRAT represents a depreciation of the exchange rate against the US dollar. An increasing value for XRAT means that more of the country's home currency is required to purchase one US dollar (Colander, 2010). GDP is the annual change in world gross domestic product (Owen, 2005; Mohamad, 2008).

Given the defined model, measures for the variables in this study, namely export performance and currency, required further explanation. Blades (2000) proposes two methods of measuring export performance. These measures include, first, the value of exports as a ratio of gross output of domestic producers; or, second, a calculation of the real growth rates of GDP of each export partner country compared with the real growth rate of exports to these countries. In the case of the latter, export market share is said to be increasing if export growth exceeds real GDP growth (Blades, 2000).

Gertner, Gertner, and Guthery (2007) present an operational definition of export performance, which includes the following financial metrics: export sales volume; export profitability; and changes in export sales or profitability. Berman and Berthou (2009), in their study of 27 developed and developing countries, utilise export volume as a measure of export performance. Export volume is used to ensure the real effects of depreciation were considered in the analysis (Berman \& Berthou, 2009). 
Sousa (2004) shows that export growth is one of the most prevalent indicators of export performance in the review of 43 empirical studies on export performance published between 1998 and 2004. As a result, this study has adopted the convention of annual percentage growth in exports of goods and services as a measure of export performance, similar to that used by Blades (2000). Exports of goods and services, as an annual percentage growth rate is based in constant home currency; and represents the value of all goods and other market services provided to the rest of the world (World Bank, 2010b). These export goods and services include merchandise, freight, insurance, transport, travel, royalties, license fees, communication, construction, financial, information, business, personal and government services; and exclude compensation of employees and investment income and transfer payments (World Bank, 2010b).

Currency depreciation, as an independent variable, is a reduction in the relative value of the exchange rate (Owen, 2005). Exchange rate, however, has numerous measures (Bautista, 1982). Burstein et al. (2004) and Owen (2005) use the real exchange rate, which is the nominal exchange rate adjusted for changes in purchasing power. Mohamad (2008) utilises an annual average exchange rate to the US dollar. Berman and Berthou (2009) use domestic currency in terms of special drawing rights (SDR) to account for competitiveness gains. SDR is an international reserve asset created by the IMF in 1969 as a supplement to the existing reserves of member countries (IMF, n.d.). SDR effectively serves as an artificial currency used by the IMF (IMF, n.d.). Real effective exchange rates would have been preferred in this study. However, due to constraints in data 
availability, annual average exchange rate to the US dollar (XRAT) has been used (Mohamad, 2008). Goldberg and Tille (2010) argue that the use of the US dollar as a measurement base is appropriate due to the extensive use of US dollars in international trade invoicing.

\subsection{Unit of Analysis}

The unit of analysis is an economy, specifically efficiency-driven economies as defined by the respective hypotheses and the World Economic Forum Global Competitiveness Report (Schwab, 2010).

\subsection{Population and Sample}

\subsubsection{Population}

The population of this study is defined as efficiency-driven economies, which are global, industrialising economies that have experienced substantial industrial growth, fuelled by exports (Clark, 1996). As export growth is the dependant variable in this study, such a measure is most relevant to economies, such as efficiency-driven economies, which seek export-led growth (Schwab, 2010).

The World Economic Forum Global Competitiveness Report 2010- 2011 defines efficiency-driven economies as 'Stage Two' economies with a GDP per capita (in US $\$$ ) of between $\$ 3000$ and $\$ 9000$ (Schwab, 2010), as shown in Table 2. GDP per capita at market rates is a widely available measure which has been used here 
as a proxy for wages, as internationally comparable data on wages are not available for all countries covered (Schwab, 2010).

A second criterion used to determine the stage of development is the extent to which a country is factor driven (Schwab, 2010). This is measured by the share of exports of mineral goods in total exports of goods and services; assuming that countries that export more than 70 percent of mineral products are to a large extent factor driven (Schwab, 2010). Efficiency-driven economies have a 40 percent weighting based on basic or factor driven requirements, as shown in Table 3. 
Table 2: List of Economies at Each Stage of Development.

\begin{tabular}{|c|c|}
\hline Stage 1 Economies & $\begin{array}{l}\text { Bangladesh, Benin, Bolivia, Burkina Faso, Burundi, } \\
\text { Cambodia, Cameroon, Chad, Cote d'Ivoire, Ethiopia, } \\
\text { Gambia, The Ghana, Honduras, India, Kenya, Kyrgyz } \\
\text { Republic, Lesotho, Madagascar, Malawi, Mali, } \\
\text { Mauritania, Moldova, Mongolia, Mozambique, Nepal, } \\
\text { Nicaragua, Nigeria, Pakistan, Philippines, Rwanda, } \\
\text { Senegal, Tajikistan, Tanzania, Timor-Leste, Uganda, } \\
\text { Vietnam, Zambia, Zimbabwe }\end{array}$ \\
\hline Transition from 1 to 2 & $\begin{array}{l}\text { Algeria, Angola, Armenia, Azerbaijan, Botswana, } \\
\text { Brunei, Darussalam, Egypt, Georgia, Guatemala, } \\
\text { Guyana, Indonesia, Iran, Islamic Rep., Jamaica, } \\
\text { Kazakhstan, Kuwait, Libya, Morocco, Paraguay, Qatar, } \\
\text { Saudi Arabia, Sri Lanka ,Swaziland, Syria, Ukraine, } \\
\text { Venezuela }\end{array}$ \\
\hline Stage 2 Economies & $\begin{array}{l}\text { Albania, Argentina, Bosnia and Herzegovina, Brazil, } \\
\text { Bulgaria, Cape Verde, China, Colombia, Costa Rica, } \\
\text { Dominican Republic, Ecuador, El Salvador, Jordan, } \\
\text { Lebanon, Macedonia, FYR Malaysia, Mauritius, } \\
\text { Mexico, Montenegro, Namibia, Panama, Peru, } \\
\text { Romania, Russian Federation, Serbia, South Africa, } \\
\text { Thailand, Tunisia, Turkey }\end{array}$ \\
\hline Transition from 2 to 3 & $\begin{array}{l}\text { Bahrain, Barbados, Chile, Croatia, Estonia, Hungary, } \\
\text { Latvia, Lithuania, Oman, Poland, Puerto Rico, Slovak } \\
\text { Republic, Taiwan (China), Trinidad and Tobago, } \\
\text { Uruguay }\end{array}$ \\
\hline Stage 3 Economies & $\begin{array}{l}\text { Australia, Austria, Belgium, Canada, Cyprus, Czech } \\
\text { Republic, Denmark, Finland, France, Germany, } \\
\text { Greece, Hong Kong SAR, Iceland, Ireland, Israel, Italy, } \\
\text { Japan, Korea, Rep., Luxembourg, Malta, Netherlands, } \\
\text { New Zealand, Norway, Portugal, Singapore, Slovenia, } \\
\text { Spain, Sweden, Switzerland, United Arab Emirates, } \\
\text { United Kingdom, United States }\end{array}$ \\
\hline
\end{tabular}

Source: (Schwab, 2010)

Table 3: Weights of the Three Main Sub-Indexes at Each Stage of Development

\begin{tabular}{|l|c|c|c|}
\hline \multicolumn{1}{|c|}{ Sub-index } & $\begin{array}{c}\text { Factor- } \\
\text { driven } \\
\text { stage (\%) }\end{array}$ & $\begin{array}{c}\text { Efficiency- } \\
\text { driven } \\
\text { stage (\%) }\end{array}$ & $\begin{array}{c}\text { Innovation- } \\
\text { driven } \\
\text { stage (\%) }\end{array}$ \\
\hline Basic requirements & 60 & 40 & 20 \\
\hline Efficiency enhancers & 35 & 50 & 50 \\
\hline Innovation and sophistication factors & 5 & 10 & 30 \\
\hline
\end{tabular}

Source: (Schwab, 2010) 


\subsubsection{Sampling Approach}

A non-probability, judgement based sampling approach has been utilised (Blumberg et al., 2008). This is in line with the approach taken by Santos-Paulino (2002) and Razmi (2007). While a purposive sampling approach may have resulted in the selection of a biased sample, this is deliberate as the benefits of such a method outweigh the costs (Blumberg et al., 2008). A non-probability, judgement based sampling approach facilitates a screening process to ensure appropriate sample members may be selected (Blumberg et al., 2008). In such exploratory research, where existing literature on the relationship between currency weakness and export performance is mixed, the non-probability approach allows for the relationship to be explicitly tested and in turn provide a platform for later investigation (Blumberg et al., 2008).

Certain criteria have been applied to the population of 29 efficiency-driven economies in Table 2 to facilitate sample selection. The population of efficiencydriven economies has characteristics that are widely varying and significantly different. The results achieved for one may therefore not be representative of another. As a result, these criteria have been designed to establish a set of countries which have a high degree of commonality. In addition, the criteria exclude those employed in determination of the population as discussed above (GDP per capita and factor-driven weighting). 
The criteria used in the selection of the sample for this study include the specific, de facto exchange rate arrangements which are then broadly classified as fixed or floating exchange rate arrangements, as denoted in Table 1 (IMF, 2008); percentage of GDP derived from manufacturing value-added (to approximate the percentage of the economy that is manufacturing based) (World Bank, 2009); and population number (United Nations, 2010). Manufacturing value-added is the net output of a sector after adding up all outputs and subtracting intermediate inputs (World Bank, 2009). This criterion is calculated without making deductions for depreciation or depletion of natural resources to denote gross manufacturing value-added (World Bank, 2009).

Thresholds have been applied to each criterion for the purposes of sample selection. First, only economies with floating exchange rate arrangements have been selected. This is done to isolate the effect of market forces to depreciate or weaken the currency value (Owen, 2005), as opposed to a policy decision. In addition, under IMF rules, large devaluations are no longer necessary as corrective measures as small, gradual exchange rate adjustments are deemed more effective (Bautista, 1982). Second, economies with greater than ten percent manufacturing value added as a percentage of GDP have been included in the sample. This is because industrialising nations should have substantial manufacturing sectors to support export-oriented economic growth (Chow, 1987). Third, populations greater than one million people were required to ensure only economies of significant size were selected. 
Table 4: Efficiency-Driven Economies

\begin{tabular}{|c|c|c|c|c|}
\hline \multicolumn{2}{|c|}{$\begin{array}{l}\text { Stage } 2 \text { Economies- } \\
\text { The Population }\end{array}$} & \multirow{2}{*}{\begin{tabular}{|l}
\multicolumn{1}{c}{ Broad } \\
category of \\
exchange rate \\
arrangement
\end{tabular}} & \multirow{2}{*}{$\begin{array}{l}\begin{array}{c}\text { Manufacturing, } \\
\text { value added, as } \\
\% \text { GDP }\end{array} \\
20 \%\end{array}$} & \multirow{2}{*}{$\begin{array}{l}\begin{array}{l}\text { Population } \\
\text { ('000) }\end{array} \\
3,169 \\
\end{array}$} \\
\hline 1 & Albania & & & \\
\hline 2 & Argentina & Fixed & $21 \%$ & 40,666 \\
\hline 3 & $\begin{array}{l}\text { Bosnia and } \\
\text { Hertzegovina }\end{array}$ & Fixed & $13 \%$ & 3,760 \\
\hline 4 & Brazil & Floating & $15 \%$ & 195,423 \\
\hline 5 & Bulgaria & Fixed & $15 \%$ & 7,497 \\
\hline 6 & Cape Verde & Fixed & $7 \%$ & 513 \\
\hline 7 & China & $\begin{array}{l}\text { Pegged } \\
\text { Floating }\end{array}$ & $34 \%$ & $1,354,146$ \\
\hline 8 & Colombia & Floating & $14 \%$ & 46,300 \\
\hline 9 & Costa Rica & $\begin{array}{l}\text { Pegged } \\
\text { Floating }\end{array}$ & $19 \%$ & 4,640 \\
\hline 10 & $\begin{array}{l}\text { Dominican } \\
\text { Republic }\end{array}$ & Floating & $24 \%$ & 10,225 \\
\hline 11 & Ecuador & Fixed & $10 \%$ & 13,775 \\
\hline 12 & El Salvador & Fixed & $21 \%$ & 6,194 \\
\hline 13 & Jordan & Fixed & $20 \%$ & 6,472 \\
\hline 14 & Lebanon & Fixed & $9 \%$ & 4,255 \\
\hline 15 & Macedonia, FYR & Fixed & $23 \%$ & 2,043 \\
\hline 16 & Malaysia & Floating & $25 \%$ & 27,914 \\
\hline 17 & Mauritius & Floating & $19 \%$ & 1,297 \\
\hline 18 & Mexico & Floating & $17 \%$ & 110,645 \\
\hline 19 & Montenegro & Fixed & $6 \%$ & 626 \\
\hline 20 & Namibia & Fixed & $15 \%$ & 2,212 \\
\hline 21 & Panama & Fixed & $6 \%$ & 3,508 \\
\hline 22 & Peru & Floating & $14 \%$ & 29,496 \\
\hline 23 & Romania & Floating & $22 \%$ & 21,190 \\
\hline 24 & $\begin{array}{l}\text { Russian } \\
\text { Federation }\end{array}$ & Fixed & $15 \%$ & 140,367 \\
\hline 25 & Serbia & Floating & $9 \%$ & 9,856 \\
\hline 26 & South Africa & Floating & $15 \%$ & 50,492 \\
\hline 27 & Thailand & Floating & $34 \%$ & 68,139 \\
\hline 28 & Tunisia & Fixed & $16 \%$ & 10,374 \\
\hline 29 & Turkey & Floating & $17 \%$ & 75,705 \\
\hline
\end{tabular}

Source: (IMF, 2008; Schwab, 2010; World Bank, 2009; United Nations, 2010) 
Data pertaining to the sample criteria for each economy are denoted in Table 4. Based on the applied thresholds, a sample of 12 economies remained. A further two economies, Albania and Romania, were excluded from the sample due to a lack of data availability in the early 1990s, which coincides with the presence of communist regimes present in these countries at such time. Therefore, a sample of ten economies remained, as shown in Table 5.

Table 5: Sample of Efficiency-Driven Economies

\begin{tabular}{|c|c|c|c|c|}
\hline \multicolumn{2}{|c|}{$\begin{array}{c}\text { Stage } 2 \\
\text { Economies- The } \\
\text { Sample }\end{array}$} & \multirow{2}{*}{$\begin{array}{l}\begin{array}{l}\text { Floating Exchange } \\
\text { rate arrangement }\end{array} \\
\text { Managed Float with no } \\
\text { pre-determined path }\end{array}$} & \multirow{2}{*}{$\begin{array}{l}\begin{array}{c}\text { Manufacturing, } \\
\text { value added, } \\
\text { as \% GDP }\end{array} \\
34 \% \\
\end{array}$} & \multirow{2}{*}{$\begin{array}{l}\begin{array}{c}\text { Population } \\
\text { ('000) }\end{array} \\
68,139 \\
\end{array}$} \\
\hline 1 & Thailand & & & \\
\hline 2 & Malaysia & $\begin{array}{l}\text { Managed Float with no } \\
\text { pre-determined path }\end{array}$ & $25 \%$ & 27,914 \\
\hline 3 & $\begin{array}{l}\text { Dominican } \\
\text { Republic }\end{array}$ & $\begin{array}{l}\text { Managed Float with no } \\
\text { pre-determined path }\end{array}$ & $24 \%$ & 10,225 \\
\hline 4 & Mauritius & $\begin{array}{l}\text { Managed Float with no } \\
\text { pre-determined path }\end{array}$ & $19 \%$ & 1,297 \\
\hline 5 & Mexico & Independently floating & $17 \%$ & 110,645 \\
\hline 6 & Turkey & Independently floating & $17 \%$ & 75,705 \\
\hline 7 & Brazil & Independently floating & $15 \%$ & 195,423 \\
\hline 8 & South Africa & Independently floating & $15 \%$ & 50,492 \\
\hline 9 & Colombia & $\begin{array}{l}\text { Managed Float with no } \\
\text { pre-determined path }\end{array}$ & $14 \%$ & 46,300 \\
\hline 10 & Peru & $\begin{array}{l}\text { Managed Float with no } \\
\text { pre-determined path }\end{array}$ & $14 \%$ & 29,496 \\
\hline
\end{tabular}

Source: (IMF, 2008; Schwab, 2010; World Bank, 2009; United Nations, 2010)

The sample of efficiency-driven economies shown in Table 5 are ranked in descending order, first by manufacturing value add and second by population. These ten economies have been reviewed for a period of 20 years, from 1990 to 
2009. Given the limitations of such a sampling approach, it was not anticipated that the sample would be representative of the entire population (Blumberg et al., 2008). However, the sample is indicative of efficiency-driven economies with floating rate exchange rate arrangements.

\subsection{Data Collection and Analysis}

As the sample of ten economies is reviewed for 20 years, secondary, historical data was used for purposes of this study. Such data was obtained from macroeconomic databases, which include the Penn World Table (Heston, Summers, \& Aten, 2011) and the World Bank (2010b, 2011). The required variables for analysis included annual percentage growth in exports of goods and services, GDP and XRAT for the required sample from 1990 to 2009.

\subsection{Research Limitations}

This research contains certain limitations or exclusions due to the method selected. Given the focus on floating exchange rate arrangements, the sample may not be considered representative of the entire population. As this population is limited to efficiency-driven economies, inferences may not be made for factor- or innovationdriven economies, including those in transition stages (refer Table 2) (Schwab, 2010). Further, analysis of export performance has been performed at an aggregate level (Owen, 2005). This study therefore ignores industry-level effects; which includes export sector concentration. 
Following the approach taken by Calvo and Reinhart (2000), exchange rate arrangements, as denoted by the IMF (2008), are accepted as de facto. No analysis has therefore been performed to ensure exchange rate arrangements are evident in reality; nor assess the effect of official or unofficial intervention in a country's exchange rate. The effect of unintended consequences or the social costs, such as diminished national wealth or an increased cost of living, also have been excluded for purposes of this research (Owen, 2005).

The effects of currency weakness on the overall trade balance (Musila \& Newark, 2003) and imports have not been addressed. In addition, the effect of currency weakness on imported inputs to production, export duties and the resultant impact on export performance or profitability has not been considered (Gertner et al., 2007).

Annual average exchange rate to the US dollar has been used as a representative measure for currency. The US dollar has been used as a benchmark based on international trade trends (Goldberg \& Tille, 2010). However, no analysis has been performed on the impact of the relative strength or weakness of the US dollar on these measures.

Further, there is a lack of consideration for the supply side effects of currency depreciation on export performance (Berman \& Berthou, 2009). Supply-side effects include foreign currency denominated borrowings; credit constraints; and 
the balance sheet effect that currency weakness may induce and potentially reduce firms' production capabilities or their ability to compete in the export market (Berman \& Berthou, 2009). Potential currency depreciation effects on increased domestic supply are also excluded (Bautista, 1982). A decrease in the price of exported goods relative to home goods may discourage the expansion of export supply as it becomes more profitable to expand domestic supply (Bautista, 1982). 


\section{Results}

As discussed in Chapter Three, two hypotheses are under investigation. These hypotheses were:

H1: Export growth is improved by currency depreciation in efficiency-driven economies.

H2: Improvements in export growth lag currency depreciation in an efficiencydriven economy.

Descriptive statistics have been used to give an overview of the sample data in Section 5.1. Preliminary analysis is then performed to obtain an initial indication of the existence of a relationship, as well as data fit to the respective models. The hypotheses are then investigated using a panel data model with fixed effects, as stated in Chapter Four.

\subsection{Sample Data and Descriptive Statistics}

Annual observations for the percentage export growth (World Bank, 2010b) and $X R A T$ (Heston et al., 2011) were obtained for all ten countries for the period 1990 to 2009. This data, displayed in Appendix 9.2, equated to 200 observation points in total across the sample.

Preliminary analysis is aided by a visual presentation of the data (Albright, Winston, \& Zappe, 2009). A box plot representation of export growth across each of the ten countries over the twenty year time period is displayed in Figure 2. 
Figure 2: Export Growth by Country

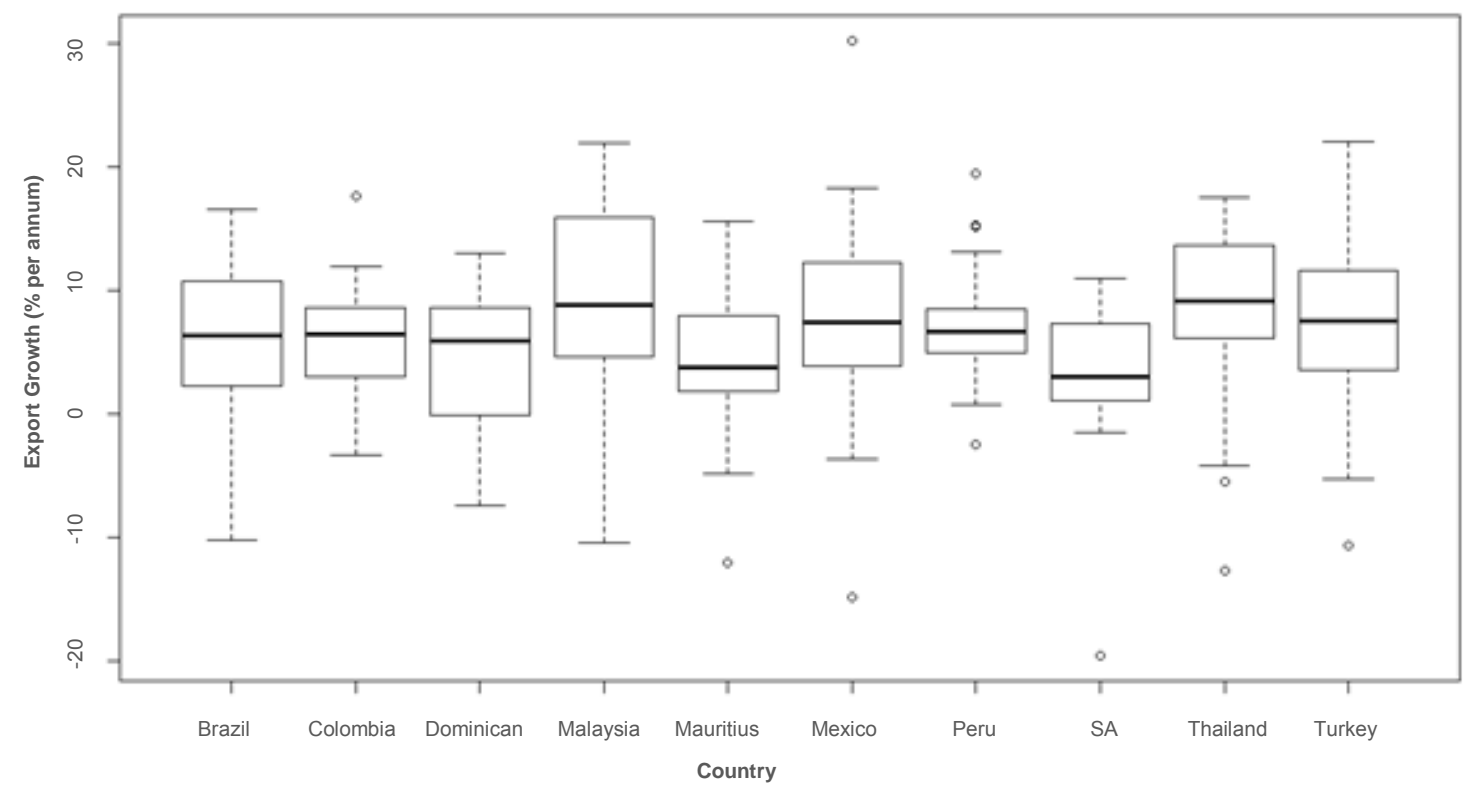

The greater the length of the box plot (Albright et al., 2009), the greater the variance in export growth data for a country. Such large variance in data points, as is seen in the case of Brazil, Malaysia and Turkey, can be interpreted as volatility in export growth. Narrower box plots, as is seen in the instance of South Africa, would indicate less variance in export growth data and hence less volatility.

However, box plots do not show the mean value of a data set (Albright et al., 2009). Table 6 illustrates the mean or average annual export growth values over the twenty year period. The mean values of export growth per country show that, on average, certain countries within the sample have higher export growth rates than others. 
Table 6: Average Annual Export Growth (1990 to 2009)

\begin{tabular}{|l|r|}
\hline \multicolumn{1}{|c|}{ Country } & Average Annual Export Growth (\%) \\
\hline Brazil & $6.0 \%$ \\
\hline Colombia & $5.6 \%$ \\
\hline Dominican Republic & $4.1 \%$ \\
\hline Malaysia & $8.7 \%$ \\
\hline Mauritius & $3.9 \%$ \\
\hline Mexico & $8.1 \%$ \\
\hline Peru & $7.4 \%$ \\
\hline South Africa & $3.2 \%$ \\
\hline Thailand & $7.9 \%$ \\
\hline Turkey & $7.7 \%$ \\
\hline
\end{tabular}

Outliers are unusual values within a dataset and may inflate the standard deviation from the mean values (Albright et al., 2009), as shown in Table 6. The predominance of outliers, noted in Figure 2, relates to poor export market performance in 2009 during the global financial crisis. Data for 2009, as shown in Figure 3, shows a significant decline in annual export growth for all ten countries, with all countries experiencing export market contraction or negative growth.

$X R A T$ by country for the period 1990 to 2009 is shown in Figure 4 . The length of the box plot is again indicative of variance in the data. The longer the box plot, the more variance or volatility the exchange rate displays against the US dollar. 
Figure 3: Export Growth by Year (1990 to 2009)

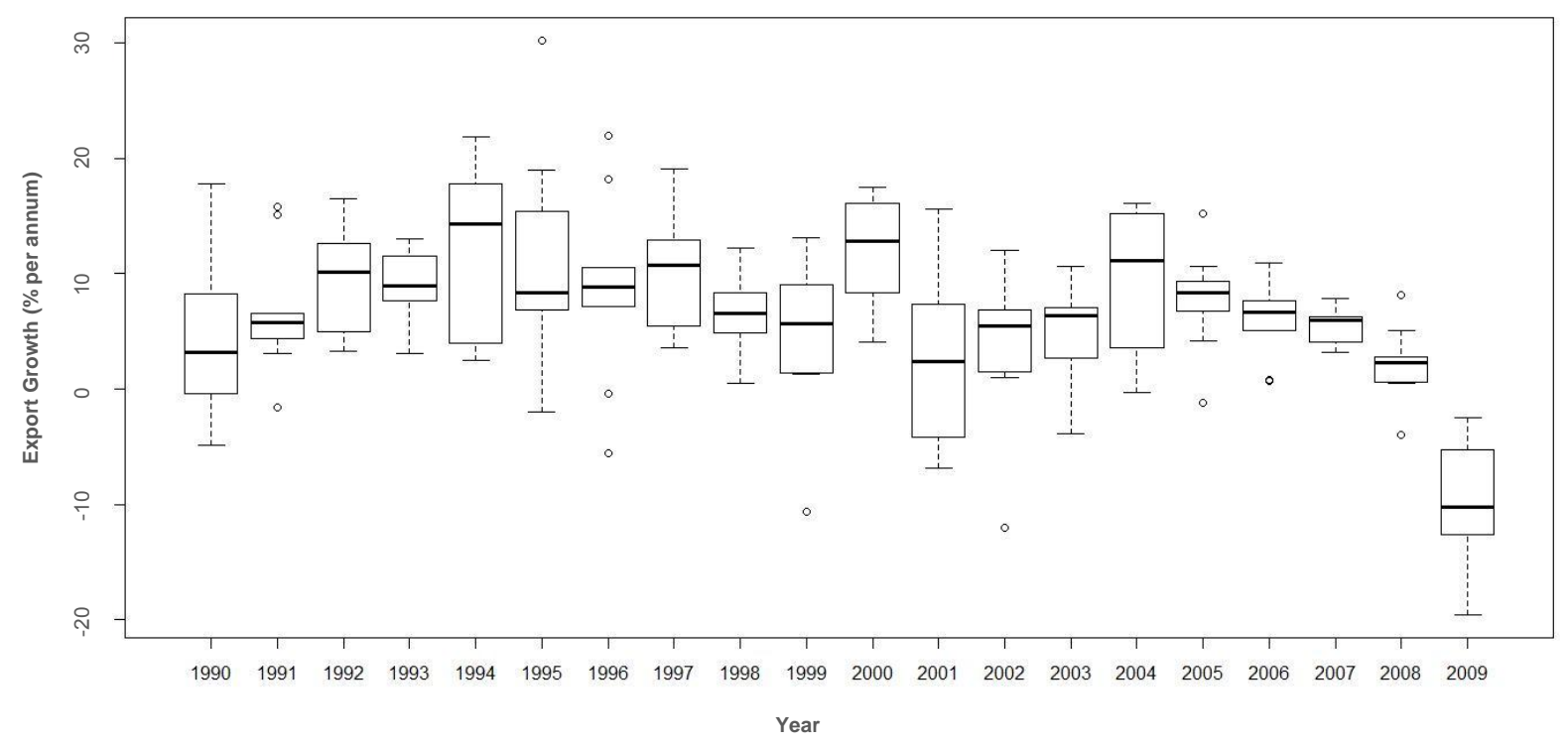

Figure 4: XRAT by Country

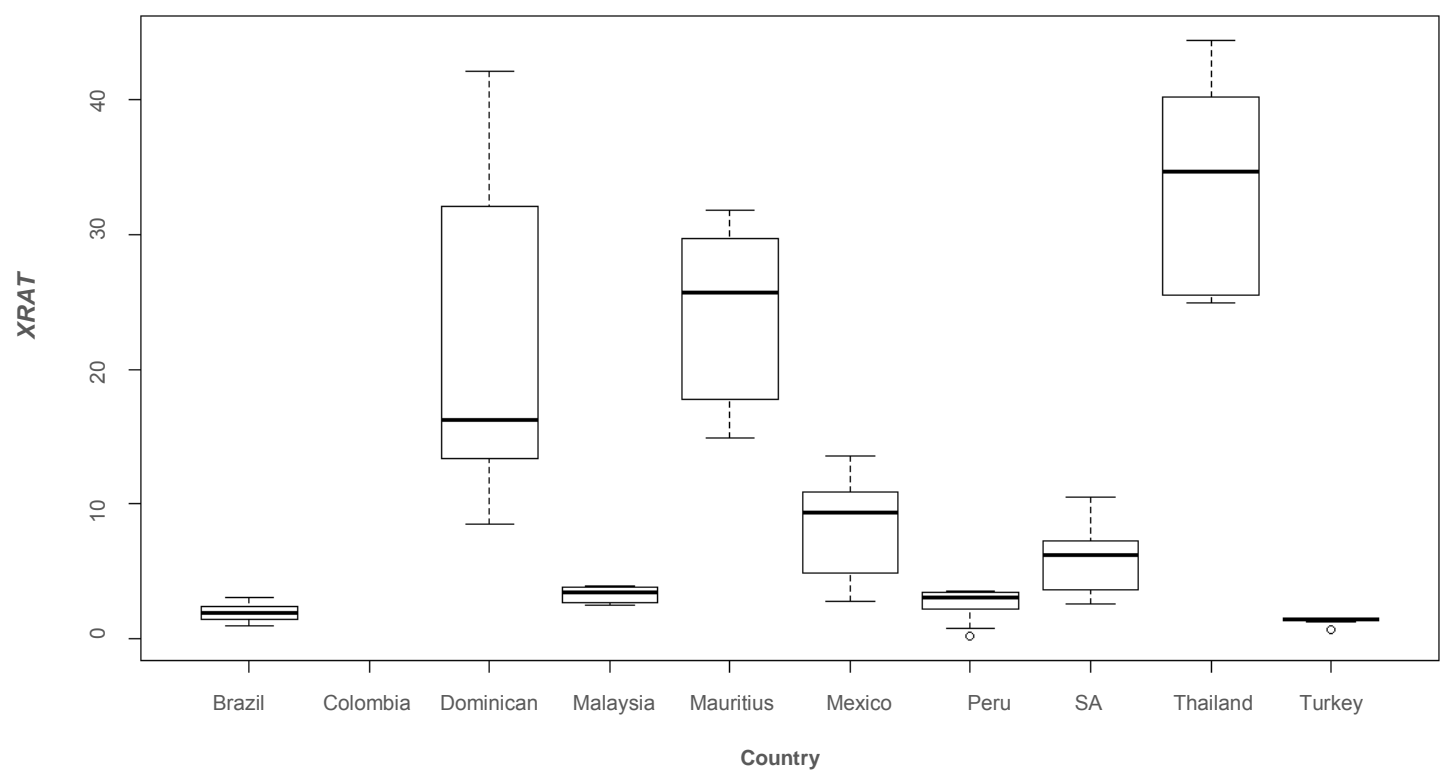

Anomalies in the underlying data are seen for Malaysia for the period 1999 to 2004, when the Malaysian Ringgit was fixed at 3.8 to the US dollar (Talib, 2006), 
before reverting back to a floating exchange rate arrangement. However, this does not have a distortionary effect on the data. Representative data for Colombia, however, is shown off the top of the boxplot in Figure 4 due to the Colombian Peso being extremely weak against the US Dollar. Inflationary pressures have also resulted in high denominations for the Peso, which contribute to this effect. This creates significant distortions in the overall data and has hence been excluded for the purposes of testing in Section 5.2. The sample size is therefore reduced to nine countries, with 180 data points which remain available for observation.

Figure 5: Combined XRAT (1990 to 2009)

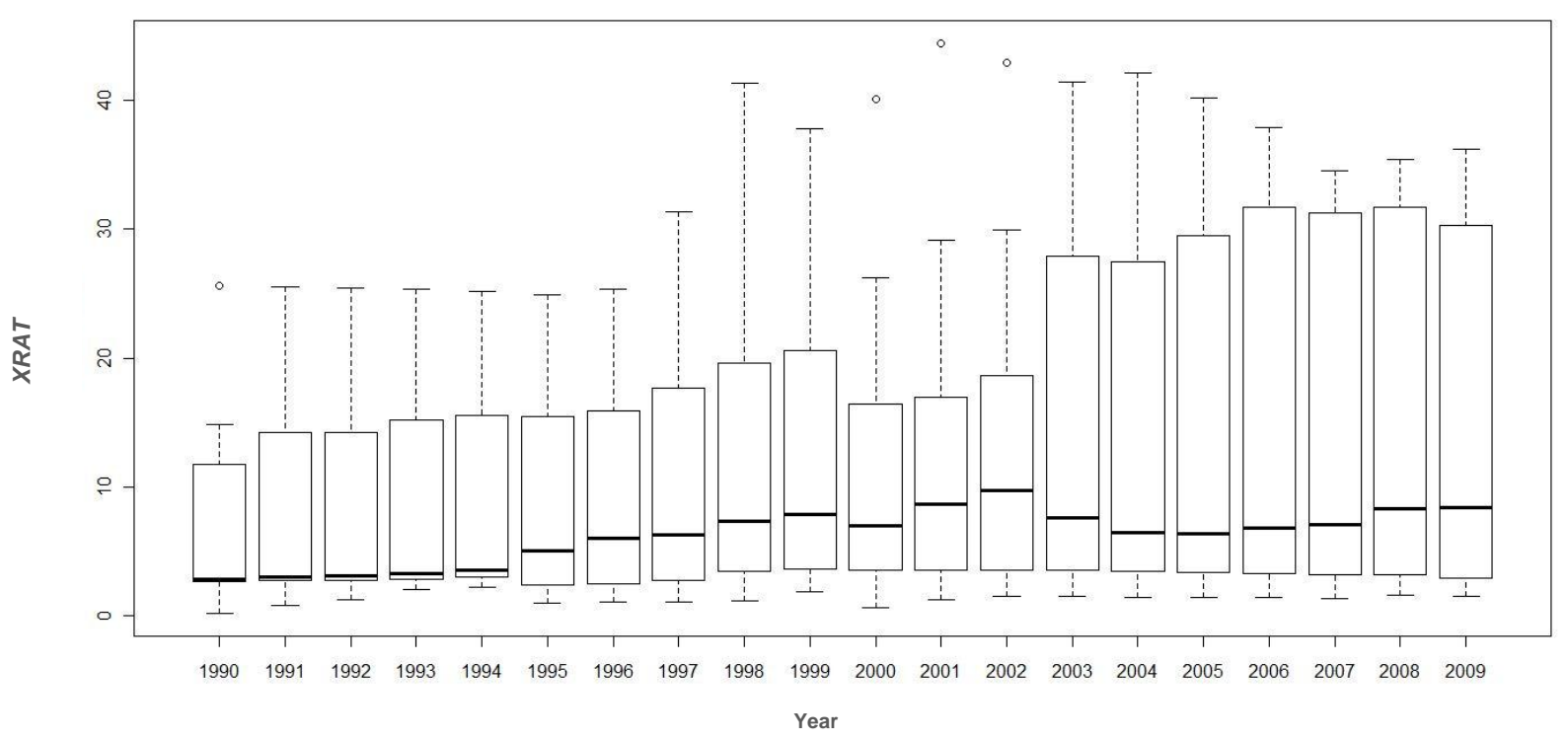

A view of the combined $X R A T$ for all nine countries over the twenty year period, as shown in Figure 5, displays an overall trend of depreciation or weakening against the US Dollar. Figure 4 reveals that certain exchange rates are consistently weaker against the US Dollar over the twenty year time period. This is seen in the 
case of Thailand, Mauritius and the Dominican Republic. Whilst the exchange rates of the nine countries weakened against the US Dollar, as shown in Table 7, the Brazilian Real, the Turkish Lira and the Peruvian Sol showed a more significant depreciation.

Table 7: Percentage by which the Currency has Depreciated against the US Dollar (1990 to 2009)

\begin{tabular}{|l|r|}
\hline \multicolumn{1}{|c|}{ Country } & $\begin{array}{r}\text { Percentage by which the Currency } \\
\text { has Depreciated against the US } \\
\text { Dollar (1990 to 2009) }\end{array}$ \\
\hline Brazil & $-7,005,746.3 \%$ \\
\hline Dominican Republic & $-324.7 \%$ \\
\hline Malaysia & $-26.4 \%$ \\
\hline Mauritius & $-103.8 \%$ \\
\hline Mexico & $-364.3 \%$ \\
\hline Peru & $-1,438.2 \%$ \\
\hline South Africa & $-225.1 \%$ \\
\hline Thailand & $-30.2 \%$ \\
\hline Turkey & $-57,017.9 \%$ \\
\hline
\end{tabular}

In the case of Turkey and Brazil the effect is particularly noticeable. The low base figures for 1990 for Turkey and Brazil may, however, distort these results somewhat. Turkey experienced significant intervention with regards to the Lira during the 1990s, as the currency was artificially appreciated in an effort to counteract significant inflationary pressures (Akyüz \& Boratav, 2003). This ten year period, from 1990 to 1999 , has been excluded from the data to prevent distortions. In the case of Brazil, as the Real was only adopted in 1994. Prior to that, Brazil had the Cruzeiro from 1990 to 1993 and the Cruzeiro Real from 1993 to 
1994 (Garcia \& Valpassos, 1998). The conversion to the Real was a redenomination to account for significant inflationary pressures experienced in Brazil during this period. This five year period up until 1994, before adoption of the Real, has therefore been excluded due to a distortionary effect on the data. The removal of these fifteen data points eliminates these distortions as shown in Table 8. 165 data points therefore remain and have been used in subsequent testing.

Table 8: Percentage by which the Currency has Depreciated against the US Dollar (1990 to 2009)

\begin{tabular}{|l|r|}
\hline \multicolumn{1}{|c|}{ Country } & $\begin{array}{r}\text { Percentage by which the Currency } \\
\text { has depreciated against the US } \\
\text { Dollar (1990 to 2009) }\end{array}$ \\
\hline Brazil (1995 to 2009) & $-89.6 \%$ \\
\hline Dominican Republic & $-324.7 \%$ \\
\hline Malaysia & $-26.4 \%$ \\
\hline Mauritius & $-103.8 \%$ \\
\hline Mexico & $-364.3 \%$ \\
\hline Peru & $-1,438.2 \%$ \\
\hline South Africa & $-225.1 \%$ \\
\hline Thailand & $-30.2 \%$ \\
\hline Turkey (2000 to 2009) & $-138.3 \%$ \\
\hline
\end{tabular}

The effects of changes in the exchange rate arrangement, as well as currency volatility, have not been considered in this study. These concepts do, however, provide areas for future research as noted in Chapter Seven. 


\subsection{Hypothesis One: Export Growth is Improved by Currency Depreciation in Efficiency-Driven Economies}

The first hypothesis tests whether export growth is improved by currency depreciation in efficiency-driven economies. As an initial test of a relationship between XRAT and export growth, an ordinary least squares (linear) regression was run. From this regression, $X R A T$ is not deemed statistically significant as the $\mathrm{p}$-value is 0.12 , which is greater than 0.5 . The adjusted $r$-squared is 0.01 , indicating a very weak fit of the model as only one percent of the variance in export growth is explained by $X R A T$.

The adjusted r-squared is preferred as a measure when compared to the multiple $r$-squared, as the multiple r-squared may be artificially inflated when using a number of variables in a test (Albright et al., 2009). Such an effect may exist here

given the number of variables used, hence the adjusted r-squared is used as a measure of the coefficient of determination instead (Albright et al., 2009). The relationship between export growth and $X R A T$ is graphically shown by a scatterplot with a linear regression line fitted in Figure 6. Visual inspection indicates the linear relationship displayed is weak. 
Figure 6: Scatterplot of Export Growth and XRAT with a Linear Regression Line

Fitted

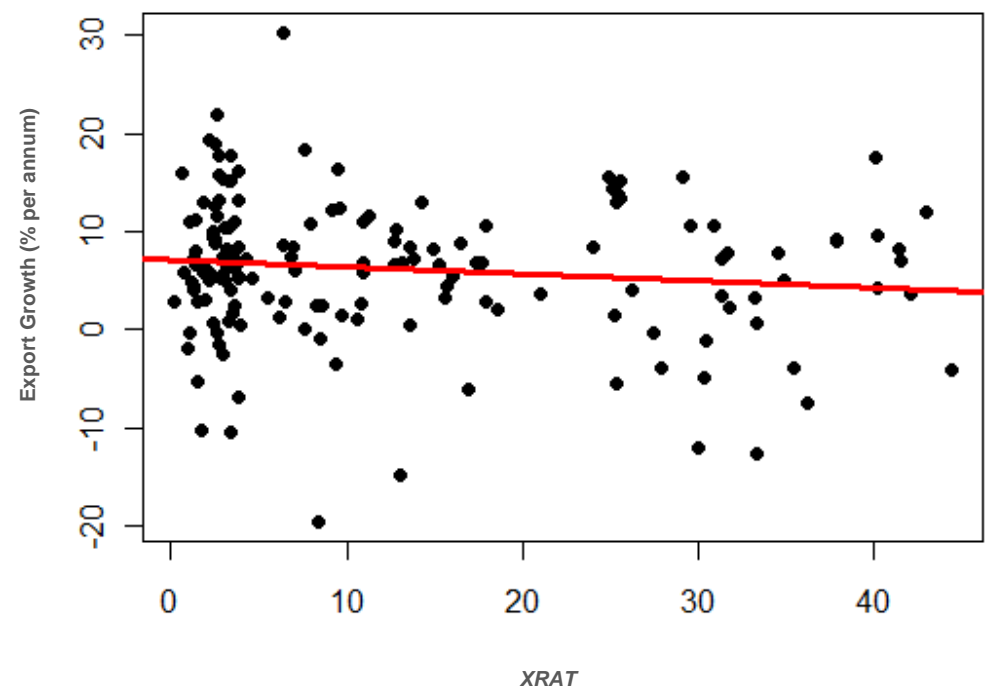

To analyse the relationship between export growth and XRAT for the individual countries, scatterplots with a linear regression line fitted were plotted for each country, as shown in Figure 7 . Visual inspection of Figure 7 reveals differing relationship trends for each individual country, with a predominance of inverse relationships displayed. 
Figure 7: Scatterplot of Country Export Growth and XRAT with a Linear

\section{Regression Line Fitted}

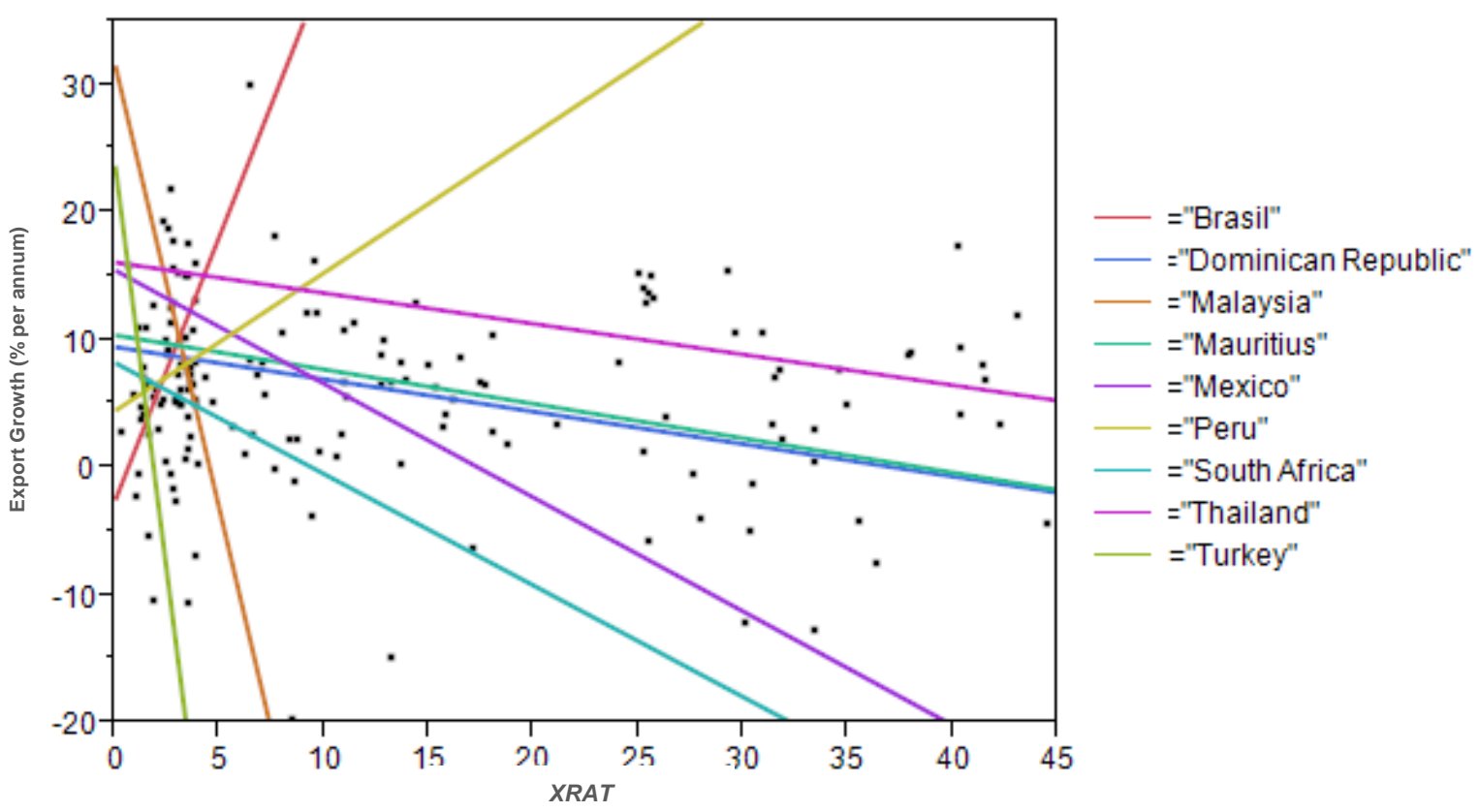

Exceptions to the inverse relationships are Peru and Brazil, as observed in Figure

7. Preliminary visual analysis of the inverse relationships for the remaining seven countries out of the sample of nine, indicate that as export growth increases, so $X R A T$ decreases.

When GDP is introduced into the ordinary least squares regression model, as described in Chapter Four, the fit of the model changed. The overall fit of the model is statistically significant as the p-value is less than 0.01 at a $95 \%$ confidence level. However, $X R A T$ is not deemed statistically significant, as the $\mathrm{p}$ value of 0.07 is greater than 0.05 . $G D P$ is therefore a more significant indicator of export growth with a p-value less than 0.01 , being less than 0.05 . The adjusted $r$ - 
squared is 0.31 indicating a reasonable fit as $31 \%$ of export growth is explained by $G D P$, as $X R A T$ is not found to be statistically significant.

To assess the effect of country on the data, a fixed regression model with dummy variables for country is run. Overall, the fit of the model is statistically significant as the p-value is less than 0.01 at a $95 \%$ confidence level. The effect of XRAT was also significant as the $p$-value of 0.01 is less than 0.05 . The adjusted $r$-squared is 0.47 , indicating a reasonable fit, as $47 \%$ of export growth is explained by $X R A T$ and country. Tested individually, the effect of country and XRAT on export growth was significant as all $p$-values were less than 0.05 , as shown in Table 9.

Table 9: Fixed Regression Results for the Effect of XRAT and Country on Export Growth

\begin{tabular}{|c|c|c|c|c|}
\hline Coefficients & Estimate & $\begin{array}{c}\text { Standard } \\
\text { Error of } \\
\text { Sample } \\
\text { Distribution }\end{array}$ & \multicolumn{2}{|c|}{$p$-value } \\
\hline$X R A T$ & -0.30 & 0.11 & ** & 0.01 \\
\hline Brazil & 6.34 & 1.78 & *** & $>0.01$ \\
\hline Dominican Republic & 10.56 & 2.74 & *** & $>0.01$ \\
\hline Malaysia & 9.64 & 1.57 & *** & $>0.01$ \\
\hline Mauritius & 11.24 & 2.99 & *** & $>0.01$ \\
\hline Mexico & 10.63 & 1.77 & *** & $>0.01$ \\
\hline Peru & 8.20 & 1.56 & $* * *$ & $>0.01$ \\
\hline South Africa & 4.95 & 1.65 & ** & $>0.01$ \\
\hline Thailand & 18.25 & 3.92 & *** & $>0.01$ \\
\hline Turkey & 6.82 & 2.17 & ** & $>0.01$ \\
\hline Significance codes: & $0.001^{\text {‘** }}$ & $0.01^{\text {‘*’ }}$ & $5 \because$ & $0.1 “ " 1$ \\
\hline
\end{tabular}


However, when $G D P$ is introduced to the fixed regression model, the statistical significance changes. Overall, the fit of the model remains statistically significant as the p-value is less than 0.01 at a $95 \%$ confidence level. The effect of XRAT and $G D P$ is statistically significant with p-values of less than 0.01 . GDP, however, displays a stronger significance than XRAT. Tested individually, the effect of country, GDP and XRAT on export growth is only significant for Thailand, as shown in Table 10. The adjusted $r$-squared was 0.65 , indicating a reasonable fit, as $65 \%$ of export growth is explained by XRAT, GDP and country. This result, however, should be interpreted with caution as the composite model may artificially inflate the coefficient of determination.

Table 10: Fixed Regression Results for the Effect of XRAT, GDP and Country on Export Growth

\begin{tabular}{|c|c|c|c|c|}
\hline Coefficients & Estimate & $\begin{array}{c}\text { Standard } \\
\text { Error of } \\
\text { Sample } \\
\text { Distribution }\end{array}$ & \multicolumn{2}{|c|}{$p$-value } \\
\hline$X R A T$ & -0.28 & 0.09 & ** & $>0.01$ \\
\hline GDP & 2.75 & 0.3 & $* * *$ & $>0.01$ \\
\hline Brazil & 1.29 & 1.67 & & 0.44 \\
\hline Dominican Republic & 2.85 & 2.38 & & 0.23 \\
\hline Malaysia & 2.27 & 1.51 & & 0.13 \\
\hline Mauritius & 3.48 & 2.57 & & 0.18 \\
\hline Mexico & 3.17 & 1.65 & . & 0.06 \\
\hline Peru & 0.85 & 1.5 & & 0.57 \\
\hline South Africa & -2.47 & 1.57 & & 0.12 \\
\hline Thailand & 10.31 & 3.3 & ** & $>0.01$ \\
\hline Turkey & -0.29 & 1.93 & & 0.88 \\
\hline
\end{tabular}


During model development in Section 4.1, the fixed-effects method of panel data analysis was deemed preferable based upon similar research. This assertion is tested against the ordinary and pooled least squares methods, as well as the random effects method. In testing whether ordinary least squares method is preferable to fixed effects, the null hypothesis that the ordinary least squares method is a better fit than the fixed method was rejected as the p-value was less than 0.01 . The alternative hypothesis, that fixed effects are significant, is therefore accepted as the p-value was less than 0.05 . This indicates that the fixed model is a significant improvement on the ordinary least squares model.

The Swamy-Arora's transformation is then used to test for random effects within the model (Bond, 2002). Random effects were also significant as the p-value of less than 0.01 . Using a pooled least squares model, the overall fit of the model is also significant, with a p-value of less than 0.01 . However, upon examination of the coefficients, only $G D P$ is significant with a p-value of less than 0.01. XRAT, with a p-value of 0.07 is not statistically significant. Using this method, with an adjusted $r$-squared of 0.32 , the inference is that $32 \%$ of export growth is explained by $G D P$.

To test for panel effects and ascertain whether random effects or a least squares method was more appropriate, a Breusch-Pagen Lagrange multiplier test is performed (Bond, 2002). The null hypothesis here was that there is no panel effect and that a least squares method is more appropriate; whereas the alternate 
hypothesis is that there is a panel effect. With a p-value of less than 0.01 , the alternate hypothesis was accepted, indicating that panel effects are in existence. The random effects model is therefore an improvement on the ordinary and pooled least squares models.

As panel effects are in existence, a Hausman test was therefore used to ascertain whether a fixed-effects or random-effects method would be more appropriate for this study (Torres-Reyna, 2010). Given results noted previously within Section 5.2, the fixed and random models would be acceptable, however, one method must be selected. The null hypothesis in this test was that the preferred model is random effects. Whereas, the alternative hypothesis was that the fixed-effects method is preferred. The resultant $p$-value of 0.06 allows us to accept the alternate hypothesis and use fixed effects, as the p-value is less than 0.1. A significance cut-off of 0.1 is deemed appropriate for the Hausman test (Torres-Reyna, 2010). Baltagi (2005) argues that where the p-value is less than 0.05 , the fixed model must be used, and where the p-value is less than 0.1 the fixed model remains appropriate. Given this result, the fixed model is confirmed as appropriate and has been used.

With the fixed-effects method confirmed, a number of additional tests were performed to ascertain the existence of certain effects within the data model. Baltagi (2005) states that cross-sectional dependence may be problematic in macro-level panels with a long time-series. This may arise from the presence of common shocks and unobserved components within the data due to economic and 
financial integration of countries, which may imply strong interdependencies within the cross-sectional units in the panel (Baltagi, 2005). The Breusch-Pagan LM test and the Pesaran CD test for cross-sectional dependence in panels were run, where the resultant $p$-values were 0.06 and 0.21 respectively. The $p$-values in each of the tests were greater than 0.05 , indicating that cross-sectional dependence does not exist.

Serial correlation tests were also applied, as macro panels with long time series may display correlation over time (Baltagi, 2005). The Breusch-Godfrey/ Wooldridge test is used for serial correlation in panel models, whereby the null hypothesis was that there is no serial correlation (Baltagi, 2005). As the p-value of 0.18 is greater than 0.05 , the null hypothesis is not rejected and serial correlation does not exist within the model.

Stationarity is another test that is performed on panel models. A stationary process has no seasonality and displays a mean, variance and autocorrelation structure that does not change over time (Torres-Reyna, 2010). The Dickey-Fuller test was used to test for stationarity, where the null hypothesis was that the series is nonstationary. With a p-value of 0.01 being less than 0.05 , the null hypothesis is rejected. Rather, the alternate hypothesis that the process is stationary was accepted. A stationary process is a favourable outcome and hence no further data transformation was required (Baltagi, 2005). 
Heteroskedascity was the final test applied to ascertain the existence of differing variance within the data (Torres-Reyna, 2010). The converse of heteroskedascity is homoskedascity. Homoskedascity is the vertical spread of data around a predicted regression line that is fairly constant as $x$ changes. As a result, where homoskedascity exists, the estimated standard error, confidence intervals and hypothesis tests can be relied upon in a panel model (Baltagi, 2005). The Breusch-Pagan test was used to test for heteroskedascity, and if the p-value is less than 0.05 heteroskedascity exists. In the instance of this model, the p-value was 0.07 , hence no evidence of heteroskedascity is found.

Given the preceding analysis, the panel model with fixed effects was confirmed as appropriate. Using a panel data model, without $G D P$, the model fit and exchange rate was deemed significant. P-values of 0.01 respectively are deemed statistically significant as the values are less than 0.05 . However, the adjusted $r$-squared was only 0.05 , indicating that only $5 \%$ of export growth is explained by $X R A T$.

Upon introduction of GDP into the combined panel data model, the overall fit of the model improved as the p-value was less than 0.01. XRAT and GDP are significant individually with $\mathrm{p}$-values of less than 0.01 respectively. $G D P$ is, however, more significant as a coefficient of determination when compared to $X R A T$, given the $\mathrm{p}$ values stated above. With an adjusted $r$-squared of $0.35,35 \%$ of the model could now be explained by $X R A T$ and $G D P$. There is little guidance as to what an acceptable adjusted $r$-squared value is, however this is a fair value as one third of 
the variance may be explained by the two independent variables: $G D P$ and $X R A T$. A high adjusted r-squared value may indicate multicollinearity (Albright et al., 2009), however, this is not applicable here.

Given the statistical significance of $G D P$ in the previous panel model, a separate, panel data model was then run using only $G D P$ as an independent variable. The fit of the model and GDP were significant with p-values less than 0.01 . The adjusted r-squared was 0.27 , hence $27 \%$ of variance in export growth may be explained by $G D P$. When compared to adjusted r-squared values of 0.05 for XRAT alone and 0.35 for the combined model, the variables together have a slightly better explanatory power in terms of impact on export growth.

The direction of the relationships is further explained upon examination of the estimates or coefficients for $X R A T$ and $G D P$, which are -0.28 and 2.75 respectively. The sign of each coefficient indicates the direction of the relationship between export growth and the two independent variables: $X R A T$ and $G D P$. In the case of $G D P$ and export growth, there is a positive or direct relationship. As GDP increases, so too does export growth. XRAT, however, has a negative coefficient and therefore a negative or inverse relationship with export growth. As export growth increases, so $X R A T$ decreases. 
A similar inverse or negative relationship was observed at an individual country level for seven out of the nine countries tested. These individual relationships are shown by the estimate coefficient for each country, as displayed in Table 11 . However, as the hypothesis was testing for a relationship at an overall level, the composite model shall be used as the predominant test for the impact of $X R A T$ on export growth.

Table 11: Estimates by Country

\begin{tabular}{|l|r|}
\hline \multicolumn{1}{|c|}{ Country } & \multicolumn{1}{c|}{ Estimate } \\
\hline Brazil & 4.2 \\
\hline Dominican Republic & -0.3 \\
\hline Malaysia & -7.0 \\
\hline Mauritius & -0.3 \\
\hline Mexico & -0.9 \\
\hline Peru & 1.1 \\
\hline South Africa & -0.9 \\
\hline Thailand & -0.2 \\
\hline Turkey & -12.9 \\
\hline
\end{tabular}

\subsection{Hypothesis Two: Improvements in Export Growth Lag Currency Depreciation in Efficiency-Driven Economies}

In order to ascertain whether improvements in export growth lag currency depreciation in an efficiency-driven economy, a one year lag effect was applied to $X R A T$ in the model to ascertain the existence of a time delay in the relationship. The fit of the panel model with fixed effects is statistically significant with a p-value of less than 0.01 . This is the same p-value noted in the original test in Section 5.2. Overall fit of the model has therefore remained consistent. GDP and XRAT remain 
statistically significant variables with $p$-values of less than 0.01 respectively. It is, however, important to note that the level of significance has changed as the variables have smaller $p$-values than noted in the panel model in Section 5.2. Fit of the independent variables within the model has therefore improved slightly.

The resultant coefficients for $G D P$ and $X R A T$ are 2.73 and -0.39 respectively. $X R A T$ remains a negative coefficient and therefore an inverse relationship with export growth. Given the slightly higher absolute value of the coefficient when compared to the panel data model with fixed effects in Section 5.2, the relationship is slightly more pronounced with a time delay applied. However, this is not deemed a statistically significant improvement as the overall fit of the panel model is consistent with those achieved in Section 5.2 , hence no significant lag effects can be attributed to the relationship.

Given the significance of $G D P$ in previous tests within this research, a one year lag effect was applied to $G D P$ in order to ascertain significance. The lag applied to GDP was not found to be statistically significant with a p-value of 0.08 and an adjusted r-squared value of 0.01 .

\subsection{Summary}

The research objective required testing whether export growth is improved by currency movement. The analysis was carried out using a panel data model with 
fixed effects. Results indicated that a decrease in $X R A T$, a relative strengthening of exchange rate to the US Dollar, improves export growth, and no significant lag effects may be attributed to the relationship. This is a remarkable result at odds with mainstream argument where many developing economies, pursuant of a strategy of export-led growth, view currency weakness as favourable (Dolan, 2010). The results are discussed in Chapter 6. 


\section{Discussion of Results}

\subsection{Introduction}

The research explored the impact on export growth of currency depreciation within efficiency-driven economies. Previous studies on the relationship between currency weakness and export performance provide mixed evidence. There was a general agreement in the literature that a weakening currency impacts export performance via the mechanism of price, however direction, extent and duration of the impact were not always conclusive.

\subsection{Hypothesis One: Export Growth is Improved by Currency Depreciation in Efficiency-Driven Economies}

The research adopts a panel model constructed with two independent variables, $X R A T$ and GDP. GDP may be seen as proxy for income (Owen, 2005); whereas $X R A T$ could be seen as a measure of price from an export perspective (Todaro \& Smith, 2009). Together, XRAT and GDP provide a measure of purchasing capacity (Mohamad, 2008). The effect of each of these variables on export growth in efficiency-driven economies shall be discussed separately, prior to the analysis of the combined effect. 


\subsubsection{Exchange Rate}

Based upon the results obtained from the panel study with fixed effects in Chapter Five, $X R A T$ was found to be significant in terms of an effect on export growth for the remaining sample of nine economies. This concurs with the arguments presented by Boltho (1996) and Schwab (2010) that the strong outward, export orientation of efficiency-driven economies renders them most sensitive to currency movements.

However, as $X R A T$ has a negative coefficient, it therefore displays a negative or inverse relationship with export growth. As export growth increases, so XRAT decreases. These findings were consistent at the sample and individual country level. Seven out of the nine efficiency-driven economies displayed the inverse relationship between XRAT and export growth. Brazil and Peru were the two countries that displayed a contrary, direct relationship between XRAT and export growth. This may be as a result of the predominance of commodity-based exports for these countries, however, this is not noted in the case of South Africa which displays a similar weighting of commodity exports. Regardless, the anomalies noted with these two countries do not impact the overall findings, given that it is a sample of efficiency-driven economies under review, rather than individual countries. 
Against this backdrop, the null hypothesis that export growth is improved by currency depreciation in efficiency-driven economies is rejected. The resultant relationship indicates a decrease in $X R A T$, a relative appreciation, improves export growth. This allows an acceptance of the alternate hypothesis that export growth is not improved by currency depreciation in efficiency-driven economies.

As noted in Chapter 4, the non-probability, judgement based sampling approach may have resulted in the selection of a biased sample. However, this was deliberate to focus on efficiency-driven economies with floating exchange rate arrangements. Hence the benefits outweigh the costs, and the results are representative of efficiency-driven economies with floating exchange rate arrangements. Further, the impact of smaller sample sizes introduces the possibility of Type I hypothesis error on the rejection of the null hypothesis, and hence inaccurately making inferences on statistical significance (Albright et al., 2009).

The overall finding, however, does align with the studies done by Lizondo and Montiel (1989), Calvo and Reinhart (2000), Musila (2002), Frankel (2005) and Berman and Berthou (2009), where a weakening currency was found to have a negative effect on export performance. Berman and Berthou (2009, p. 104) reviewed 27 developed and developing countries using a similar method over a shorter time period and found that 'financial market imperfections have a negative impact on the reaction of countries' exports' to currency depreciation. This 
negative effect was particularly prevalent in developing countries with medium to high levels of foreign currency borrowing and low to intermediate levels of financial development. Efficiency-driven economies, being a sub-set of developing economies as discussed in Chapter Two, would fall within this categorisation (Schwab, 2010). Financial market imperfections have not been included in this study, yet the findings are consistent in terms of the direction of the relationship between export growth and currency depreciation.

Lizondo and Montiel (1989) and Calvo and Reinhart (2000) used a prior study analysis and time series approach, and found a similar negative impact of currency depreciation on export growth in the short run. However, found a negligible impact in the long run where the price level for an economy is completely flexible as to shifts in aggregate demand and aggregate supply (Colander, 2010). Calvo and Reinhart (2000) utilised a similar time period of twenty years over which the study was conducted. Hence, the direction of relationship and duration of effects evident are comparable to the research done here.

Quantification of the extent of the effects of currency depreciation on export growth is, however, problematic. Many studies are silent on this and, at best, refer to the effects as marginal (Bautista, 1982), moderate (Berman \& Berthou, 2009) or insignificant (Santos-Paulino, 2002) in nature. Balassa (1978) argues that export growth rates are sensitive to the choice of initial year in a study, as certain countries may start from a low base. Improvements in export growth rates may 
thus appear inflated where measurement has commenced off a low base (Balassa, 1978).

A relatively longer time period of 20 years was employed in this research to mitigate such effects. Calvo and Reinhart (2000) and Santos-Paulino (2002) employ longer time periods of 30 and 27 years respectively. Whereas Auer and Chaney (2009) and Berman and Berthou (2009) utilise a shorter time period of 11 and 16 years respectively. Certain studies reviewed a period less than ten years for a small sample of counties, as was the case of Mohamad (2008). In such instances, the shorter time period may have an impact on the results.

In addition, there are a number of ancilliary effects that could result from currency weakness, which may negate any improvement in export performance and support the findings in this research. Kamin and Rogers (2000) found that price inflation is a real risk should the real exchange rate be weakened on a sustained basis. Significant price inflation may therefore result in negative export growth, or negate any improvements, as the price of export goods effectively rises (Todaro \& Smith, 2009). Wage inflation may also have been imported with a weakened home currency, as workers may seek wage increases to protect the real purchasing power of their incomes in the face of price inflation (Owen, 2005).

Currency depreciation decreases the purchasing power of the home economy relative to other economies which it may purchase goods and services from. An 
unintended consequence of currency depreciation is therefore the weakening of the country's, and the individual's, balance sheet as purchasing power declines. Imported inputs into the production of exports may also minimise the impact of a reduced export price due to currency depreciation, as the cost of production rises (Abeysinghe \& Yeok, 1998). This may necessitate increased prices to maintain margins. In the instance where exporters reduce their profit mark-ups to remain competitive in world markets, this may not be sustainable (Abeysinghe \& Yeok, 1998). Liquat further argued (2011) that if many countries are experiencing currency depreciation simultaneously, the competitive advantage of price may be eroded.

Boltho (1996) further argues that the effect of currency depreciation on price elasticities is not always perfectly predictable. A weaker currency, and therefore cheaper export prices relative to the currency of the purchaser, may not always result in increased export sales or market growth where export goods display low price elasticity (Boltho, 1996).

Competing on the basis of a relative, weakening currency to achieve price competitiveness has, however, been seen as an economic argument since the work of Prebisch in 1964. Prebisch (1964) also became a proponent of exportoriented industrialisation as a driver of economic growth. This second argument remains evident in economies today. However, the initial argument by Prebisch (1964) was based upon an economic era where fixed exchange rate arrangements were predominant (Dooley et al., 2004). In the current global economic landscape, 
floating exchange rate arrangements are now more prevalent (World Bank, 2010a).

The basis for much of this early work on currency weakness may not apply to the current economic context, and in particular to efficiency-driven economies with floating exchange arrangements.

Research done by Bautista (1982), Abeysinghe and Yeok (1998), Musila and Newark (2003) and Auer and Chaney (2009), still maintains that currency weakness improves export performance. Of this research, only Bautista (1982) analysed a wider sample of 23 developing nations. However, the period over which this research was performed, seven years from 1973 to 1979, was considerably shorter than the previous studies mentioned with contrary findings. Abeysinghe and Yeok (1998), Musila and Newark (2003) and Auer and Chaney (2009) all reviewed individual nations, being Singapore, Malawi and the United States of America respectively. Regardless of time period and method used, few inferences may be made across wider populations of countries, as the effects may be deemed to be isolated given the population under review in each respective study.

Given the mixed findings in previous research on this topic, the findings presented in this research adds weight to those studies which do not find currency weakness as a valid means to improve export growth, and therefore economic growth, through price competitiveness. Competing on the basis of currency may further be seen as 'self-defeating' (Liaquat, 2011, p. 97) due to the ancilliary effects that are associated with it, as well as the negligible longer term effects. Competitive 
advantage to improve export performance should therefore be sought elsewhere, in fundamental productivity within a country (Econometrix, 2011).

\subsubsection{World Gross Domestic Product}

$G D P$ was also found to be a significant variable in the determinant of export growth, and was noted to be a more significant coefficient of determination when compared to $X R A T$ in Chapter 5. GDP and export growth display a positive or direct relationship, therefore, as $G D P$ increases so too does export growth.

As discussed, GDP may be seen as proxy for income (Owen, 2005); whereas $X R A T$ could be seen as a measure of price from an export perspective (Todaro \& Smith, 2009). It therefore follows that, as GDP displays a greater significance than $X R A T$, export growth may be impacted to a greater extent by income, as opposed to price. This argument is further supported by the visual representation in Figure 3, where export growth contracts significantly during the financial crisis. For the period 1990 to 2009,2009 was the only year to display a negative GDP (Appendix 9.2). This is, however, an extreme case due to the global financial crisis experienced in 2009.

Whilst each variable has a significant effect on the variance of export growth, the combined effect is even more significant. The adjusted $r$-squared value of 0.35 
indicates that $35 \%$ of the variance in export growth may be explained by $X R A T$ and GDP. Together, XRAT and GDP provide a measure of purchasing capacity (Mohamad, 2008) and the combined effect is therefore more significant than price $(X R A T)$ or income $(G D P)$ in isolation.

\subsection{Hypothesis Two: Improvements in Export Growth Lag Currency Depreciation in Efficiency-Driven Economies}

$X R A T$ remains a negative coefficient when a lag effect was applied to the model in Section 5.3, and therefore displays a consistent inverse relationship with export growth. It therefore holds that when export growth increases, so $X R A T$ decreases. This is seen as a relative appreciation in the exchange rate (Colander, 2010).

However, given the slightly higher absolute value of the coefficient when compared to the panel data model with fixed effects in Section 5.2, the relationship is slightly more pronounced with a time delay applied. However, no significant lag effects may be attributed to the relationship given this statistically insignificant increase.

Based upon this finding, the null hypothesis is therefore rejected. This is based upon the inverse relationship, where a relative appreciation in $X R A T$ leads to export growth; as well no significantly attributable lag effects in evidence. Junz and Rhomberg (1973) found that the lag effects of price competitiveness, achieved through a depreciated currency, may take as long as one year to 18 months to present themselves. One would therefore not expect an immediate impact on 
export growth, rather a delayed one. However, no significant lag effects may be attributed given the results found in Section 5.2. An explanation for this might include the fact that lag effects take longer than 12 months to manifest themselves. An area for future research might include the testing of longer lag periods on export growth.

\subsection{Summary}

The findings therefore reject the null hypotheses in hypothesis one and hypothesis two. A weakening currency is not seen to improve export growth and the lag effect of currency movement on export performance is not significant. In this vein, it may be concluded that the research objectives have been achieved as the impact and lag effect of a weakening currency on export performance have been established. 


\section{Conclusions and Recommendations}

\subsection{Conclusions}

The purpose of the research was to assess whether efficiency-driven economies, developing nations which aim to achieve substantial industrial growth fuelled by exports (Clark, 1996), could achieve export growth through the price competitiveness effect of currency depreciation. Prebisch (1964) developed the early arguments that currency weakness was a means to boost export performance through price competitiveness. Subsequent research has produced mixed results, hence further understanding in this field was warranted.

The research found that a weakening currency does not improve export performance. Contrary to popular thinking, the findings show that export growth is associated with a stronger, relative floating exchange rate in efficiency-driven economies. The lag effect of exchange rate movement on export performance is slightly more pronounced, but remains statistically insignificant.

The association of export growth with a relative exchange rate appreciation infers a greater purchasing capacity relative to economies with a weaker currency. The research further found that, whilst $X R A T$ and $G D P$ were statistically significant, $G D P$ displayed a greater statistical significance than XRAT in improving export performance. It therefore follows that export growth may be impacted to a greater extent by income as opposed to price. 
The enhanced purchasing capacity associated with a relative, stronger exchange rate may therefore avoid the social costs and unintended consequences often produced by a weaker exchange rate. These include a diminished balance sheet, more expensive imports, a reduction in the affordability of foreign denominated debt, price inflation, wage inflation and diminished margins where imports are inputs into production.

Rather 'exports are driven by fundamental productivity, factor endowments and demand from abroad' (Econometrix, 2011, p. 3). Comparative advantage and efficiency enhancements, which are particularly relevant to efficiency-driven economies (Schwab, 2010), therefore require focus to drive export growth in such economies. This is opposed to unofficial or official intervention in the country's exchange rates. As purchasing behaviour adjusts to currency distortions over the longer term, such intervention is often rendered futile and may constitute a malinvestment of resources (Econometrix, 2011).

\subsection{Recommendations}

The research has policy implications concerning exchange rate as a tool to promote export-led growth. Current global conditions, where many economies are under financial strain or recession, have bought to prevalence the concept of competition based on currency weakness (Ahamed, 2011). Any competitive advantage conferred on export performance by a weakening currency would further deteriorate where a number of economies experience this effect 
simultaneously (Liaquat, 2011). Given the finding that a weakening currency does not improve export growth in efficiency-driven economies, this would essentially be a race to the bottom.

Declining purchasing power and a weaker balance sheet would ensure that countries, firms and individuals are in fact worse off. Further, the desired price competitiveness may not even be realised due to the vicious cycle of exchange rate pass-through to import prices, price and wage inflation.

Resources spent in attempting to weaken or manipulate the exchange rate would be wasted and attention diverted from where it is needed. Focus on improvements in fundamental productivity, efficient use of factor endowments, generating demand from abroad and providing a stable investment environment would be considerably more effective in boosting export performance (Econometrix, 2011). Prosperity gains are more likely to be seen as a result of productive practices and hard work, as opposed to a weaker currency (Econometrix, 2011).

\subsection{Future Research}

These recommendations suggest future research using, as a basis, the theory covered and observations made as part of this study. Future research could focus on the effect of exchange rate movements on export growth in factor- or innovation-driven economies. Sector based analysis could also be performed within the population of efficiency-driven economies to take account of price 
elasticity of demand and industry-level effects. Firm-level data could also be investigated to understand the supply-side effects and variation in margins of trade associated with a relative, weakening exchange rate (Berman \& Berthou, 2009).

The inclusion of further explanatory variables, such as financial market imperfections and other country specific variables would lead to a more refined model, and potentially more significant results. This was not done here in an effort to isolate the relationship between currency and export performance. A volatile exchange rate may also create an environment in which it is difficult to predict costs and prices, which may be highly disruptive to trade flows (Econometrix, 2011). Such an effect has not been considered here and would benefit from further study. More importantly, the social costs of currency depreciation, such as diminished national wealth or an increased cost of living, need to be further understood and researched (Owen, 2005).

Finally, the complexity of trade and the drivers of export performance require further understanding. The prosperity gains associated with fundamental productivity improvements (Econometrix, 2011) and the impact on export growth require further investigation. 


\section{References}

Abeysinghe, T., \& Yeok, T. (1998). Exchange Rate Appreciation and Export Competitiveness: The Case of Singapore. Journal of Applied Economics, 30, 51-55.

Acs, Z. J., Desai, S., \& Hessels, J. (2008). Entrepreneurship, Economic Development and Institutions. Small Business Economics, 31, 219-234.

Acs, Z., \& Autio, E. (2011, March 11). The Global Entrepreneurship and Development Index: A Brief Explanation. Retrieved May 29, 2011, from Imperial College of London: http://bit.ly/mVJzw9

Ahamed, L. (2011). Currency Wars, Then and Now. Foreign affairs, 90(2), 92-103.

Akyüz, Y., \& Boratav, K. (2003, September). The Making of the Turkish Financial Crisis. World Development, 31(9), 1549 - 1566.

Albright, S. C., Winston, W. L., \& Zappe, C. J. (2009). Data Analysis and Decision Making. Mason, Ohio, United States of America: South-Western Cengage Learning.

Arrow, K. J. (1963). The Economic Implications of Learning by Doing. The Review of Economic Studies, 29(3), 155-173.

Auer, R., \& Chaney, T. (2009). Exchange Rate Pass-Through in a Competitive Model of Pricing-to-Market. Journal of Money, Credit and Banking, 41(1), 151-175.

Balassa, B. (1978). Exports and Economic Growth: Further Evidence. Journal of Development Economics, 5, 181-189.

Baldauf, A., Cravens, D. W., \& Wagner, U. (2000). Examining Determinants of Export Perfromance in Small Open Economies. Journal of World Business, 35(1), 61-79.

Baltagi, B. H. (2005). Econometric Analysis of Panel Data (3rd ed.). Chichester, West Sussex, England: John Wiley \& Sons Ltd.

Bautista, R. M. (1982). Exchange Rate Variances and Export Competitiveness in Less Developed Countries under Generalised Floating. The Journal of Development Studies, 18(3), 354-378. 
Berman, N., \& Berthou, A. (2009). Financial Market Imperfections and the Impact of Exchange Rate Movements on Exports. International Review of Economics, 17(1), 103-120.

Bird, G. (1983). Should Developing Countries Use Currency Depreciation as a Tool of Balance of Payments Adjustment? A Review of the Theory and Evidence, and a Guide for the Policy Maker. The Journal of Development Studies, 19(3), 461-484.

Blades, D. (2000, May 25). Foreign Trade Statistics: Workshop on Economic Statistics. Retrieved January 15, 2011, from Organisation for Economic Cooperation and Development: http://bit.ly/rpab2c

Bloch, H., \& Sapsford, D. (2000). Whither the Terms of Trade: An Elaboration of the Prebisch-Singer Hypothesis. Cambridge Journal of Economics, 24, 461481.

Blumberg, B., Cooper, D., \& Schindler, P. (2008). Business Research Methods (2nd Edition ed.). London: McGrawHill.

Boltho, A. (1996). The Assessment: International Competitiveness. Oxford Review of Economic Policy, 12(3), 1-15.

Bond, S. (2002). Dynamic Panel Data Models: A Guide to Micro Data Methods and Practice. Retrieved April 2, 2011, from Centre for Microdata Methods and Practice: http://bit.ly/ofzQPV

Burstein, A., Eichenbaum, M., \& Rebelo, S. (2004). Large Devaluations and the Real Exchange Rate. Retrieved April 4, 2011, from IMF: http://bit.ly/qW95GE

Calvo, G. A., \& Reinhart, C. M. (2000, November). Fear of Floating. National Bureau of Economic Research.

Caves, R. E., Frenkel, J. A., \& Jones, R. W. (1990). World Trade and Payments. Boston, MA: Addison Wesley.

Chow, P. C. (1987). Causality between Export Growth and Industrial Development: Empirial Evidence from the NICs. Journal of Development Economics, 26, 55-63.

Clark, M. A. (1996). Non-traditional Export Promotion in Costa Rica: Sustaining Export-Led Growth. Journal of Interamerican Studies \& World Affairs, 37(2), 181-223. 
Colander, D. C. (2010). Macroeconomics. New York, USA: McGraw-Hill.

Diamantopoulos, A., \& Inglis, K. (1988). Identifying Differences between High- and Low-Involvement Exporters. International Marketing Review, 5(25), 52-60.

Dolan, M. (2010, October 6). Global Currency War: G20 talks needed to avert forex war. Retrieved December 9, 2010, from Reuters: http://bit.ly/o725t8

Dollar, D. (1992). Outward-Oriented Developing Economies Really Do Grow More Rapidly: Evidence from 95 LDCs. Economic Development and Cultural Change, 40(3), 523-544.

Donthu, N., \& Kim, S. H. (1993). Implications of Firm Controllable Factors on Export Growth. Journal of Global Marketing, 7(1), 47-64.

Dooley, M. P., Folkerts-Landau, D., \& Garber, P. (2004). The Revived Bretton Woods System. International Journal of Finance and Economics, 9(4), 307313.

Dougherty, C. (2006). Introduction to Econometrics (3rd ed.). Oxford: Oxford University Press.

Durand, M., \& Giorno, C. (1987). Indicators of International Competitiveness: Conceptual Aspects and Evaluation. Retrieved February 12, 2011, from Organisation for Economic Co-operation and Development: http://bit.ly/mQDV5d

ECLAC. (2007). Trade Liberalisation, Trade Performance and Competitiveness in the Caribbean. Retrieved February 4, 2011, from Economic Commission for Latin America and the Caribbean: http://bit.ly/nZfjKO

Econometrix. (2011, June 11). Further Evidence Why Rand Devaluation is a Misplaced Policy: Analysis of the Effect of Exchange Rate Volatility on the Trade Balance. Retrieved June 22, 2011, from Econometrix.

Edwards, S. (2011). Exchange Rates in Emerging Countries: Eleven Empirical Regularities from Latin America and East Asia. National Bureau of Economic Research, pp. 1-45.

Frankel, J. A. (2005). Contractionary Currency Crashes in Developing Countries. Retrieved February 10, 2011, from IMF Staff Papers: http://bit.ly/n2VnDC

Garcia, M. G., \& Valpassos, M. V. (1998). Capital Flows, Capital Controls and Currency Crisis: The Case of Brazil in the Nineties. Brazil: Pontifical Catholic University of Rio de Janeiro - Department of Economics. 
Gertner, R. K., Gertner, D., \& Guthery, D. (2007). The Implications of Export Performance Measurement for the Significance of the Determinants of Export Performance. Journal of Global Marketing, 20, 21-38.

Goldberg, L. S., \& Tille, C. (2010, April). Micro, Macro, and Strategic Forces in International Trade Invoicing. Hong Kong Institute of Monetary Research, 08(2010).

Heston, A., Summers, R., \& Aten, B. (2011, March). Penn World Table Version 7.0. Retrieved April 12, 2011, from Center for International Comparisons of Production, Income and Prices at the University of Pennsylvania: http://bit.ly/9boJg

IMF. (2008). De Facto Classification of Exchange Rate Regimes and Monetary Policy Frameworks. Retrieved April 4, 2011, from International Monetary Fund: http://bit.ly/pkwZ0g

IMF. (2009, October). World Economic Outlook. Retrieved April 11, 2011, from International Monetary Fund: http://bit.ly/ojHqhL

IMF. (n.d.). International Monetary Fund. Retrieved April 16, 2011, from Special Drawing Rights: http://bit.ly/nauL7O

Junz, H. B., \& Rhomberg, R. R. (1973). Price Competitiveness in Export Trade Among Industrial Countries. The American Economic Review, 63(2), 412418.

Kaiser, E., \& Wroughton, L. (2010, October 4). Global Currency War: Currency War Fears Tinge IMF Meetings. Retrieved December 9, 2010, from Reuters: http://bit.ly/o725t8

Kamin, S. B., \& Rogers, J. H. (2000). Output and the Real Exchange Rate in Developing Countries: An Application to Mexico. Journal of Development Economics, 61, 85-109.

Keesing, D. B. (1967). Outward-Looking Policies and Economic Development. The Economic Journal, 77(306), 303-320.

Krugman, P. R., \& Obstveld, M. (1997). International economics: Theory and Policy. Reading, MA: Addison-Wesley.

Lages, L. F. (2011). A Conceptual Framework of the Determinants of Export Performance. Journal of Global Marketing, 13(3), 29-51.

Liaquat, A. (2011). Currency Wars, Then and Now. Foreign Affairs, 90(2), 92-103. 
Lizondo, J. S., \& Montiel, P. J. (1989, March). Contractionary Devaluation in Developing Countries: An Analytical Overview. Staff papers - International Monetary Fund, 36(1), pp. 182-227.

Millman, G. J. (1990). The Floating Battlefield: Corporate Strategies in Currency Wars. Retrieved February 12, 2011, from The American Management Association: http://bit.ly/o5YsQR

Mohamad, S. (2008). Exchange Rates and Export Growth in Asian Economies. Asian Social Science, 4(11), 30-36.

Musila, J. W. (2002). Exchange Rate Changes and Trade Balance Adjustments in Malawi. Canadian Journal of Development Studies, 23, 69-85.

Musila, J. W., \& Newark, J. (2003). Does Currency Devaluation Improve Trade Balance in the Long Run? Evidence from Malawi. African Development Review, 15(2), 339-352.

Mussa, M., \& Rosen, S. (1978). Monopoly and Product Quality. Journal of Economic Theory, 18, 301-317.

Owen, J. R. (2005). Currency Devaluation and Emerging Economy Export Demand. London, England: Ashgate Publishing.

Poon, J. (1994). Effects of World Demand and Competitivesness on Exports and Economic Growth. Retrieved April 5, 2011, from Centre for Business and Economic Research, University of Kentucky: http://bit.ly/o86t8t

Porter, M. E. (1998). The Competitive Advantage of Nations. New York: The Free Press.

Prebisch, R. (1964). Towards a New Trade Policy for Development. New York: United Nations.

Prebsich, R. (1950). The Economic Development of Latin America and its Principal Problems. Lake Success: The United Nations Department of Economic Affairs.

Razmi, A. (2007). Pursuing Manufacturing-Based Export-Led Growth: Are Developing Countries Increasingly Crowding Each Other Out? Structural Change and Economic Dynamics, 18, 460-482.

Reinhart, C. M. (2000). The Mirage of Floating Exchange Rates. The American Economic Review, 90(2), 65-70. 
Rostow, W. W. (1960). The Stages of Economic Growth, a Non-Communist Manifesto. Cambridge: University Press.

Santos-Paulino, A. (2002). Trade Liberalization and Export Performance in Selected Developing Countries. Journal of Development Studies, 39(1), 140-158.

Schwab, K. (2010). The Global Competitiveness Report 2010 - 2011. Retrieved February 2, 2011, from World Economic Forum: http://bit.ly/bJ3Zfy

Sekkat, K. (2009). Does Competition Improve Productivity in Developing Countries? Journal of Economic Policy Reform, 12(2), 145-149.

Shenkar, O., \& Yagong, L. (2010). Chapter 5: Country Competitiveness (PowerPoint slides). Retrieved December 16, 2011, from International Business: http://bit.ly/oQSkFx

Sousa, C. M. (2004). Export Performance Measurement: An Evaluation of the Empirical Research in the Literature. Academy of Marketing Science Review, 9, 1-22.

Svedberg, P. (1991). The Export Performance of Sub-Saharan Africa. Economic Development and Cultural Change, 39(3), 549-566.

Talib, A. L. (2006). Pegging The Ringgit Against The US Dollar: An Evaluation. Retrieved September 1, 2011, from Statistics: http://bit.ly/g6IElb

Tan, K., \& Phang, S. (2005). From Efficiency-Driven to Innovation-Driven Economic Growth: Perspectives from Singapore. Retrieved April 1, 2011, from World Bank Policy Research Working paper 3569: http://bit.ly/o64ZHi

Todaro, M., \& Smith, S. (2009). Economic Development (6th ed.). London: Addison-Wesley.

Torres-Reyna, O. (2010). Panel Data Analysis: Fixed and Random Effects. Retrieved September 9, 2011, from Princeton University: http://bit.ly/dYKHnq

Tregarthen, T., \& Rittenberg, L. (2000). Macroeconomics (2nd ed.). New York: Worth Publishers.

United Nations. (2010). World Population Prospects. Retrieved April 4, 2011, from United Nations: Department of Economic and Social Affairs, Population Division.: http://bit.ly/qdgGft 
Vadlamannati, K. C., \& Tamazian, A. (2009). Growth Effects of FDI in 80 Developing Economies: The Role of Policy Reforms and Institutional Constraints. Journal of Economic Policy Reform, 12(4), 299-322.

World Bank. (2009). World Development Indicators Online: Manufacturing, ValueAdded (\% GDP). Retrieved April 4, 2011, from The World Bank: Development Data Group: http://bit.ly/nGvjf9

World Bank. (2010a). Data: How We Classify Countries. Retrieved April 11, 2011, from The World Bank: http://bit.ly/cgOu7t

World Bank. (2010b). Data: Exports of Goods and Services (annual \% growth). Retrieved April 16, 2011, from The World Bank: http://bit.ly/pBjdZu

World Bank. (2011). World Data Bank. Retrieved June 24, 2011, from World Development Indicators (WDI) and Global Development Finance (GDF): http://bit.ly/rnyf2n 


\section{Appendicies}

\subsection{A Summary of Past Research}

\begin{tabular}{|c|c|c|c|c|c|c|c|c|c|c|c|}
\hline 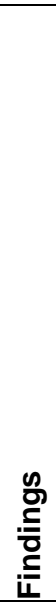 & 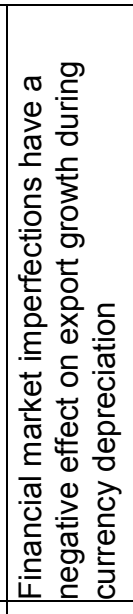 & 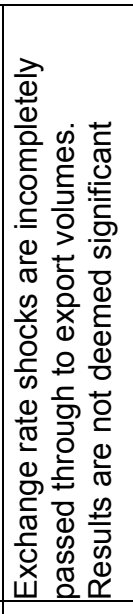 & 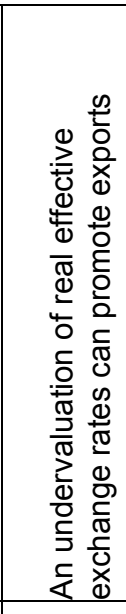 & 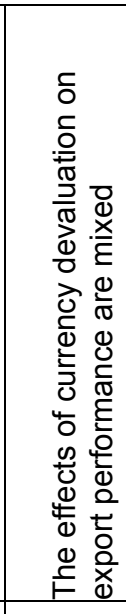 & 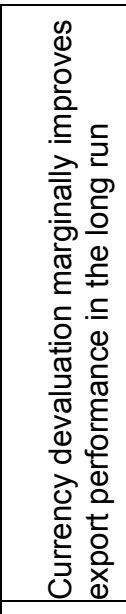 & 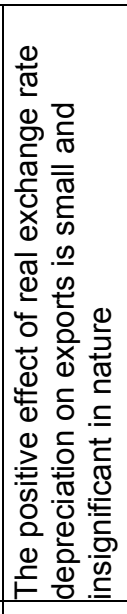 & 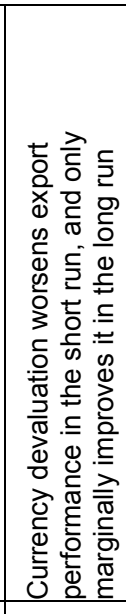 & 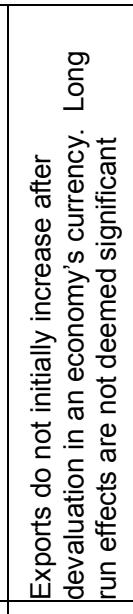 & 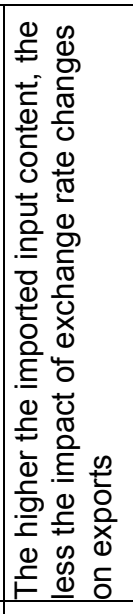 & 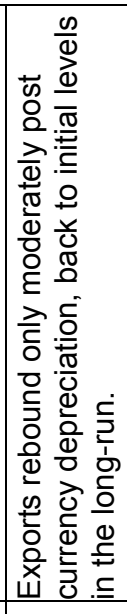 & 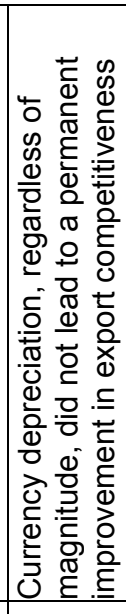 \\
\hline 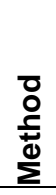 & $\begin{array}{l}\frac{\pi}{\pi} \\
\frac{0}{\pi} \\
\frac{0}{0} \\
\frac{\pi}{\pi} \\
0\end{array}$ & 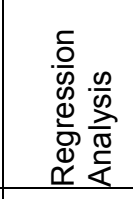 & 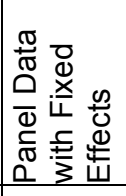 & 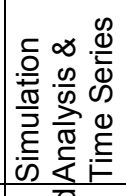 & 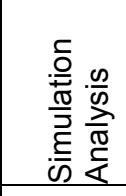 & 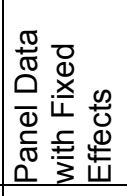 & 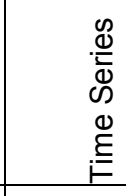 & 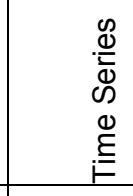 & 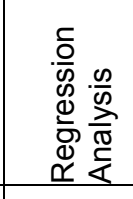 & 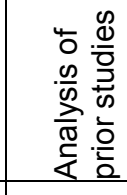 & 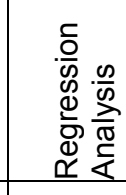 \\
\hline 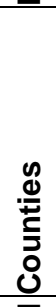 & 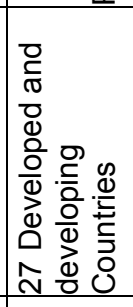 & 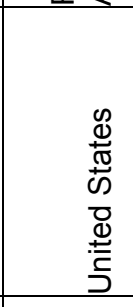 & 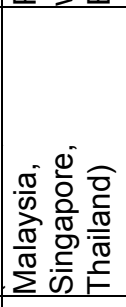 & 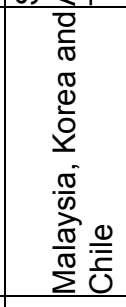 & $\begin{array}{l}\sum_{0}^{\overline{0}} \\
\frac{\pi}{\pi} \\
\sum\end{array}$ & 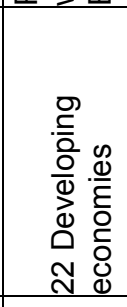 & 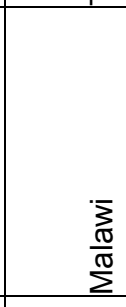 & 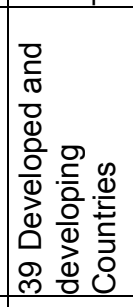 & $\begin{array}{l}0 \\
\frac{0}{0} \\
\frac{0}{\pi} \\
\stackrel{\circ}{0} \\
\text { के }\end{array}$ & 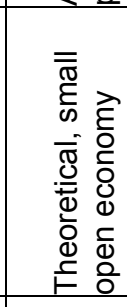 & 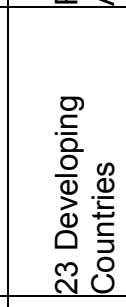 \\
\hline $\begin{array}{l}\overline{8} \\
\frac{0}{0} \\
\alpha \\
2\end{array}$ & ㅇํㅇ 융 & 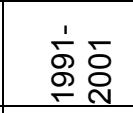 & 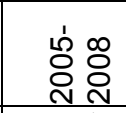 & ஜ். & 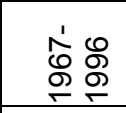 & 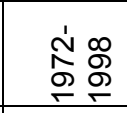 & 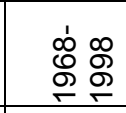 & $\begin{array}{l}\text { 용 } \\
\text { 욤 } \\
\end{array}$ & 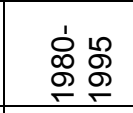 & $\frac{\pi}{c}$ & $\begin{array}{l}\text { लि } \\
\stackrel{2}{2} \\
\stackrel{2}{\circ}\end{array}$ \\
\hline త্ & 胥 & 胥 & 竞 & 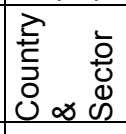 & $\begin{array}{l}\text { İ } \\
\text { 亏 } \\
\text { O }\end{array}$ & $\begin{array}{l}\text { I } \\
\stackrel{2}{5} \\
\text { O }\end{array}$ & 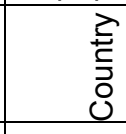 & 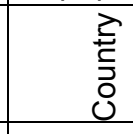 & $\begin{array}{l}\text { Z } \\
\text { 亏 } \\
0 \\
0\end{array}$ & 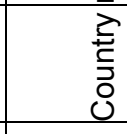 & 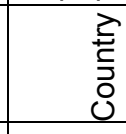 \\
\hline $\begin{array}{l}\overrightarrow{0} \\
\text { के } \\
\text { के }\end{array}$ & 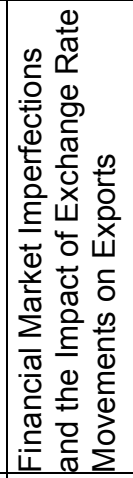 & 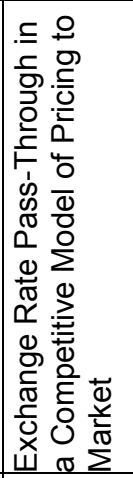 & 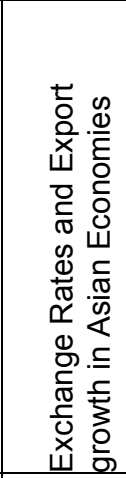 & 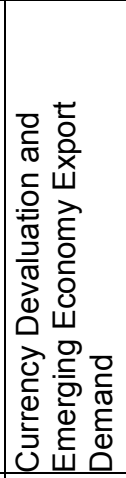 & 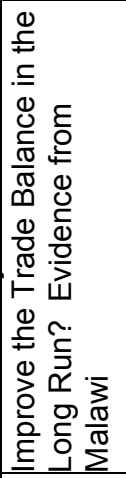 & 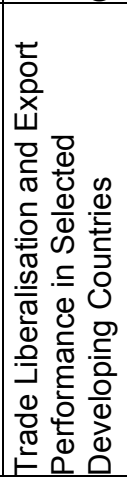 & 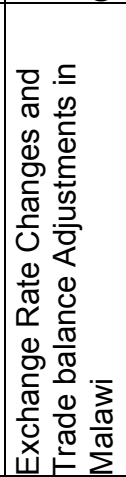 & 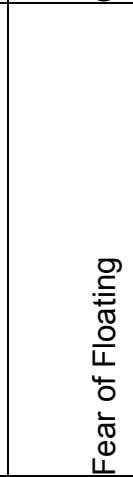 & 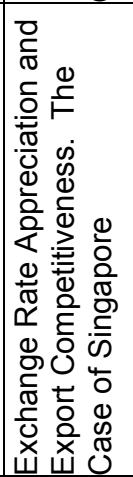 & 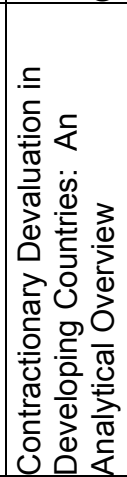 & 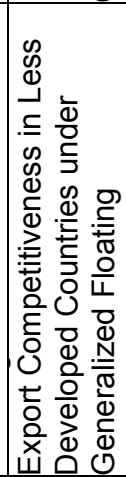 \\
\hline$\stackrel{\frac{1}{\varpi}}{>}$ & 옹 & 옹 & 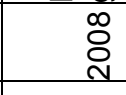 & \&్ర & ஜి & ชิ & ชิ & \&े & $\begin{array}{l}\text { \% } \\
\text { ᄋ } \\
\end{array}$ & வ & $\begin{array}{r}\text { N } \\
\stackrel{\circ}{\circ} \\
\end{array}$ \\
\hline 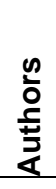 & 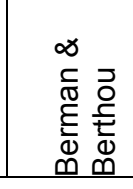 & 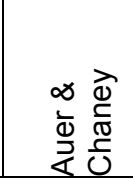 & 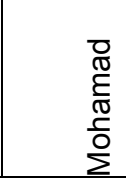 & ơ & 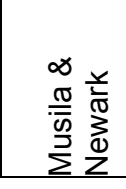 & 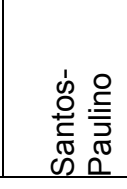 & $\frac{\frac{\pi}{\sigma}}{\frac{\omega}{2}}$ & 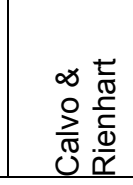 & 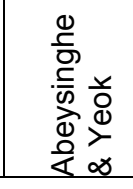 & 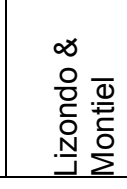 & $\frac{\pi}{00}$ \\
\hline
\end{tabular}




\subsection{Data Tables}

\begin{tabular}{|c|c|c|c|c|c|c|c|c|c|c|}
\hline 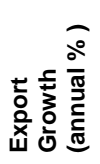 & $\begin{array}{l}\overline{\bar{N}} \\
\text { ळ! }\end{array}$ & $\begin{array}{l}\frac{\pi}{0} \\
\text { ह } \\
\text { 응 }\end{array}$ & 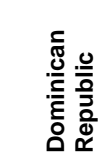 & $\frac{\frac{\pi}{\sqrt{0}}}{\frac{\pi}{\pi}}$ & 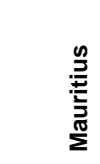 & 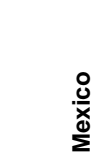 & হ & 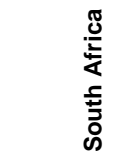 & 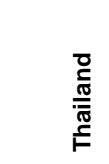 & 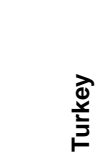 \\
\hline 1990 & -4.92185 & 17.5926 & -0.90485 & 17.81915 & 8.19917 & 5.30518 & 2.920427 & $0.4340947^{-}$ & 13.39414 & 3.15184 \\
\hline 1991 & 6.577487 & 11.94226 & 6.6 & 15.77034 & 4.356038 & 5.070252 & 5.775043 & 1.5452035 & 15.13998 & 3.1211 \\
\hline 1992 & 16.54509 & 5.568581 & 10.14034 & 12.59579 & 3.312377 & 4.984342 & 4.367793 & 5.4908183 & 13.80742 & 11.00104 \\
\hline 1993 & 11.68137 & 9.991993 & 8.933905 & 11.54254 & 6.698826 & 8.091972 & 3.109416 & 10.379009 & 12.98498 & 7.685438 \\
\hline 1994 & 4.009578 & -3.37998 & 6.828063 & 21.90672 & 2.920035 & 17.79841 & 19.38359 & 2.4852796 & 14.27754 & 15.17985 \\
\hline 1995 & -2.03282 & 3.560838 & 8.374549 & 18.96453 & 6.817227 & 30.19385 & 5.544523 & 10.937887 & 15.44494 & 7.984527 \\
\hline 1996 & -0.42 & 9.603018 & 7.10865 & 9.227955 & 10.54815 & 18.23092 & 8.880861 & 7.2040854 & -5.52475 & 21.95938 \\
\hline 1997 & 11.02129 & 3.151398 & 12.94673 & 5.49064 & 3.527228 & 10.71595 & 13.09878 & 5.2953783 & 7.233668 & 19.12386 \\
\hline 1998 & 4.90706 & 7.375476 & 6.520611 & 0.491154 & 8.328341 & 12.18392 & 5.573891 & 3.2462297 & 8.241887 & 11.9968 \\
\hline 1999 & 5.705725 & 5.923906 & 5.369726 & 13.1633 & 1.379744 & 12.32795 & 7.641542 & 1.2609066 & 9.030701 & -10.6795 \\
\hline 2000 & 12.86323 & -0.96841 & 8.736842 & 16.06573 & 4.030583 & 16.28155 & 7.991825 & 8.3136906 & 17.4881 & 15.98129 \\
\hline 2001 & 10.04571 & 2.810877 & -6.11294 & -6.83016 & 15.57597 & -3.59601 & 7.350598 & 2.3930232 & -4.21133 & 3.935617 \\
\hline 2002 & 7.416225 & -2.37741 & 1.980343 & 5.427335 & -12.063 & 1.442211 & 6.893672 & 0.9892053 & 11.9933 & 6.887231 \\
\hline 2003 & 10.40138 & 7.360296 & 10.63369 & 5.133872 & -3.85864 & 2.69362 & 6.331916 & 0.1093836 & 7.074697 & 6.855241 \\
\hline 2004 & 15.29164 & 9.808608 & 3.587915 & 16.05826 & -0.34785 & 11.5014 & 15.18375 & 2.8333398 & 9.59745 & 11.16599 \\
\hline 2005 & 9.330643 & 6.75785 & -1.24127 & 8.301907 & 10.64572 & 6.750555 & 15.20318 & 8.5676717 & 4.209828 & 7.894049 \\
\hline 2006 & 5.041518 & 7.536075 & 0.653967 & 6.589495 & 7.698939 & 10.93702 & 0.799639 & 7.4626484 & 9.146667 & 6.644856 \\
\hline 2007 & 6.198632 & 6.905083 & 3.216991 & 4.067646 & 3.43121 & 5.747028 & 6.239003 & 5.9142797 & 7.819872 & 7.264639 \\
\hline 2008 & 0.549113 & 6.111929 & -4.02109 & 1.592349 & 2.266273 & 0.460314 & 8.152643 & 2.3647345 & 5.092272 & 2.742091 \\
\hline 2009 & -10.1992 & -2.78718 & -7.42437 & -10.4175 & -4.8413 & -14.8399 & -2.46666 & 19.542129 & -12.673 & -5.25087 \\
\hline
\end{tabular}


UNIVERSITEIT VAN PRETORIA

UNIVERSITY OF PRETORIA

YUNIBESITHI YA PRETORIA

\begin{tabular}{|c|c|c|c|c|c|c|c|c|c|c|}
\hline 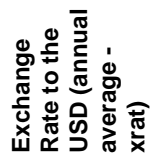 & $\begin{array}{l}\overline{\bar{N}} \\
\text { đ্ত } \\
\text { m }\end{array}$ & $\begin{array}{l}\frac{\pi}{0} \\
\text { 흠 } \\
\text { d }\end{array}$ & 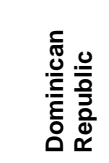 & $\frac{\frac{\pi}{\sqrt{0}}}{\frac{\pi}{\pi}}$ & 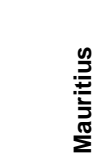 & 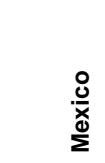 & হ ్ㅠ & 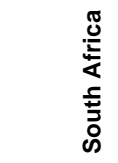 & 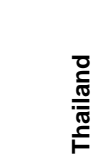 & $\begin{array}{l}\text { d } \\
\stackrel{ }{\vdots}\end{array}$ \\
\hline 1990 & $2.48 \mathrm{E}-05$ & 502.2593 & 8.5253 & 2.704875 & 14.86347 & 2.812599 & 0.187886 & 2.5873208 & 25.58546 & 0.002609 \\
\hline 1991 & 0.000148 & 633.0452 & 12.69243 & 2.750067 & 15.65231 & 3.01843 & 0.7725 & 2.761315 & 25.5168 & 0.004172 \\
\hline 1992 & 0.001641 & 759.282 & 12.77418 & 2.547383 & 15.56321 & 3.094898 & 1.245833 & 2.8520142 & 25.40013 & 0.006872 \\
\hline 1993 & 0.032163 & 863.0647 & 12.67578 & 2.574095 & 17.64803 & 3.115617 & 1.988319 & 3.2677416 & 25.31961 & 0.010985 \\
\hline 1994 & 0.639312 & 844.8359 & 13.16014 & 2.624257 & 17.96037 & 3.375117 & 2.195 & 3.5507983 & 25.14995 & 0.029609 \\
\hline 1995 & 0.917667 & 912.8264 & 13.59735 & 2.504404 & 17.38632 & 6.419425 & 2.253333 & 3.627085 & 24.91518 & 0.045845 \\
\hline 1996 & 1.0051 & 1036.686 & 13.77458 & 2.515943 & 17.94807 & 7.599448 & 2.453333 & 4.2993492 & 25.34268 & 0.081405 \\
\hline 1997 & 1.077992 & 1140.963 & 14.26548 & 2.813192 & 21.05726 & 7.91846 & 2.664167 & 4.6079617 & 31.36433 & 0.151865 \\
\hline 1998 & 1.160517 & 1426.037 & 15.26659 & 3.924375 & 23.99265 & 9.136042 & 2.93 & 5.5282842 & 41.35939 & 0.260724 \\
\hline 1999 & 1.813933 & 1756.231 & 16.03308 & 3.8 & 25.18581 & 9.560398 & 3.383333 & 6.1094842 & 37.81366 & 0.418783 \\
\hline 2000 & 1.829423 & 2087.904 & 16.41502 & 3.8 & 26.24956 & 9.455558 & 3.49 & 6.9398283 & 40.1118 & 0.625219 \\
\hline 2001 & 2.349632 & 2299.633 & 16.95162 & 3.8 & 29.12926 & 9.342342 & 3.506833 & 8.6091808 & 44.4319 & 1.225588 \\
\hline 2002 & 2.920363 & 2504.241 & 18.60983 & 3.8 & 29.962 & 9.655958 & 3.5165 & 10.540747 & 42.96008 & 1.507226 \\
\hline 2003 & 3.077475 & 2877.652 & 30.83071 & 3.8 & 27.90148 & 10.78902 & 3.478467 & 7.5647492 & 41.48462 & 1.500885 \\
\hline 2004 & 2.925119 & 2628.613 & 42.11975 & 3.8 & 27.49852 & 11.28597 & 3.413175 & 6.4596925 & 40.22241 & 1.425537 \\
\hline 2005 & 2.43439 & 2320.834 & 30.40943 & 3.787092 & 29.49623 & 10.89789 & 3.295842 & 6.3593283 & 40.22013 & 1.343583 \\
\hline 2006 & 2.175327 & 2361.139 & 33.36485 & 3.668177 & 31.70807 & 10.89924 & 3.274033 & 6.7715492 & 37.88198 & 1.428455 \\
\hline 2007 & 1.947058 & 2078.292 & 33.26279 & 3.437571 & 31.31366 & 10.92819 & 3.128045 & 7.045365 & 34.51818 & 1.30293 \\
\hline 2008 & 2.34 & 2198.09 & 35.46 & 3.46 & 31.76 & 13.54 & 3.14 & 8.248 & 34.9 & 1.53 \\
\hline 2009 & 1.74 & 2044.23 & 36.21 & 3.42 & 30.29 & 13.06 & 2.89 & 8.412 & 33.32 & 1.49 \\
\hline
\end{tabular}




\begin{tabular}{|c|c|}
\hline 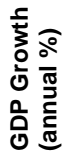 & $\begin{array}{l}\text { 흔 } \\
\text { ऐे }\end{array}$ \\
\hline 1990 & 2.974291 \\
\hline 1991 & 1.554318 \\
\hline 1992 & 2.115508 \\
\hline 1993 & 1.774183 \\
\hline 1994 & 3.301197 \\
\hline 1995 & 2.897302 \\
\hline 1996 & 3.386897 \\
\hline 1997 & 3.706939 \\
\hline 1998 & 2.368712 \\
\hline 1999 & 3.311961 \\
\hline 2000 & 4.285391 \\
\hline 2001 & 1.603491 \\
\hline 2002 & 1.957208 \\
\hline 2003 & 2.670508 \\
\hline 2004 & 4.077953 \\
\hline 2005 & 3.576396 \\
\hline 2006 & 4.012934 \\
\hline 2007 & 3.933569 \\
\hline 2008 & 1.544399 \\
\hline 2009 & -1.92636 \\
\hline
\end{tabular}

Source: (Heston, Summers, \& Aten, 2011; World Bank, 2010) 